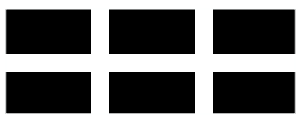

THE WILLIAM DAVIDSON INSTITUTE AT THE UNIVERSITY OF MICHIGAN BUSINESS SCHOOL

\title{
Adapting Corporate Governance for Sustainable Peace
}

By: Timothy L. Fort and Cindy A. Schipani

William Davidson Working Paper Number 532

January 2003 


\title{
ADAPTING CORPORATE GOVERNANCE FOR SUSTAINABLE PEACE
}

\author{
Timothy L. Fort, Associate Professor of Business Ethics and Business Law, University \\ of Michigan Business School; Area Director, Corporate Governance and Corporate \\ Social Responsibility, William Davidson Institute \\ and
}

Cindy A. Schipani, Professor of Business Law, University of Michigan Business School; Area Director, Corporate Governance and Corporate Social Responsibility, William Davidson Institute

\begin{abstract}
In previous work, we argued that there is a link between corporate governance and the reduction of violence. In this manuscript, we further explore that link with a focus on how corporations can work toward the goal of reduction of violence in the societies in which they operate. Here, we pose the question of how well suited various corporate governance regimes are to face these complexities, and how they can do so in ways that are consistent with their fundamental principles. We focus on the corporate governance regimes of the United States, Germany and Japan. A common denominator of the political entities addressed is a commitment to a political regime of democracy.

Section I outlines our thesis that corporations are in a position to make contributions to peace in society because of shifting political balances of power. It elaborates with the idea that our contemporary world has shifted from traditional balance of power conceptions in terms of the near universal embrace of parliamentary democracy requiring some reformulated description of the optimal relations among democracy, peace, and globalization. This section establishes the general parameters of the argument that democracy and peace are linked and that there are serious charges that globalization works against democracy and thereby threatens the sustainability of peace. Section II analyzes comparative models of corporate governance and considers the extent to which contemporary corporate governance models look to peace and workplace security as aims they should achieve. Concluding remarks follow in Section III.
\end{abstract}

Keywords: corporate governance; comparative law; business ethics; peace; democracy; globalization 


\section{ADAPTING CORPORATE GOVERNANCE FOR SUSTAINABLE PEACE ${ }^{+}$ Timothy L. Fort ${ }^{*} \&$ Cindy A. Schipani**}

In May 2002, as President Bush was preparing to embark on a trip to Germany in an attempt to convince European countries to back tougher action against Iraq, large protests sprung up in the city of Berlin. The fear of unrest prompted the German government to call over 10,000 police, the largest contingent ever assembled, into the city. ${ }^{1}$ A large composite protest group composed of 240 smaller organizations, composed of such diverse organizations as anarchists and environmentalists, which referred to itself as the Axis of Peace (in response to the labeling by President Bush of Iran, Iraq, and North Korea as the "Axis of Evil" in his 2002 State of the Union address) targeted corporations with American ties in order to express their disapproval of the current American foreign policy. ${ }^{2}$ Police had earlier thwarted an attempted firebombing on a Wal-Mart in Bonn, and they feared further attacks against the retail giant as well as against McDonald's and DaimlerChrysler. ${ }^{3}$

${ }^{+}$Copyright 2002. Timothy L. Fort \& Cindy A. Schipani. All rights reserved.

* Associate Professor Business Ethics and Business Law, University of Michigan Business School; Co-Area Director for Corporate Governance and Corporate Social Responsibility, The William Davidson Institute at the University of Michigan Business School.

** Professor of Business Law, University of Michigan Business School; Co-Area Director for Corporate Governance and Corporate Social Responsibility, The William Davidson Institute at the University of Michigan Business School. The authors wish to gratefully acknowledge the research support of the University of Michigan Business School and The William Davidson Institute and the valuable research assistance of Avec G. Gomez Lee, Elizabeth Peirce and Jill Van Dalen.

${ }^{1}$ Toby Helm, Bush Protests Off to Early Start, London Daily TeleGRAPH, May 22, 2001, at B1.

${ }^{2}$ Id.

${ }^{3} I d$. 
Of course, such protests are not limited to those groups expressing displeasure with American policy. In January 2002, Argentinian protesters ransacked Spanish and American banks and a McDonald's in Buenos Aires. These violent acts arose from what had initially been a peaceful protest aimed at economic reform by the new and unstable Argentinian government in a financial system where most of the investment is obtained from foreign sources. ${ }^{4}$

The above examples point toward an increasing trend in current global politics: the targeting of local branches of international corporations, especially American ones, in order to express disapproval with the policies of the corporation's principal place of business and/or the policies of the host country. American corporations, such as WalMart, McDonald's, Nike, and Coca-Cola are prime targets because of their size, certain business practices, and the way that these companies symbolize the capitalist free market to the rest of the world. The problem has become so troublesome and widespread that before the 2001 Summit of the Americas in Quebec City, a McDonald's in that city shut down for the duration of the event and removed all identifying signs in an attempt to escape now routine protester outbursts. ${ }^{5}$

These increasing acts of violence toward multinational corporations have important consequences for the way these companies will need to structure their approach to international business. It has thus become apparent that companies need to assure that their international business relationships are profitable on both sides. This has become more important in this era of increasingly destabilized and fluid

\footnotetext{
${ }^{4}$ Anthony Faiola, Argentine Peso Quickly Sinks After Government Lets it Float; Protests Against Economic Changes Turn Violent in Capital, WASH. Post, Jan. 13, 2002, at A23.
} 
international relationships, where the perceived dominance of one country leaves its companies that conduct international business subject to violent reprisals. Although the companies that are likely to be targeted are often the largest and most visible, they are also perceived as being the most uncaring about the conditions that they create in their host country. This has been evidenced by the ongoing debate over "sweat shop" labor that has resulted in protests against Nike both in the U.S. and abroad. Therefore, it becomes vital for these companies to strive to foster peaceful relations in the countries in which they conduct business, and to use their influence that has often worked against them in international public opinion in a positive way to attempt to create a peaceful environment in which to conduct beneficial business relations.

Relatedly, violence is not limited to the international front. The United States has one of the highest rates of workplace violence in the world, with over 2 million instances reported. ${ }^{6}$ In $2000,11 \%$ of the 5,914 fatal work injuries experienced in the United States were due to some form of violence. ${ }^{7}$ The increasing pressure of a global recession that has ignited new rounds of workplace violence is not only occurring in the United States, though. In Japan, the sagging economy has led to rapidly increasing instances of "bullying" of white-collar workers, as the idea of an individual remaining with one company for his entire working career and being able to count on that company is rapidly becoming one of the past. $^{8}$

\footnotetext{
${ }^{5}$ Protesters in Quebec Tear Down Part of Barricade, Throw Objects at Police, ST. LouIS Post-DisPatch, April 21, 2001, at 6.

${ }^{6}$ Bureau of Justice Statistics (2001) National Crime Victimization Survey 1993-1999.

${ }^{7}$ Bureau of Labor Statistics (2002) National Census of Fatal Occupational Injuries 2000.

${ }^{8}$ Duncan Chappell, Violence at Work, InTERnATIONAL LabOUR OfFICE, 2000, at 166.
} 
These incidences take a toll on the workers themselves and on the countries' economies. In the United States alone, instances of workplace violence are estimated to cost American companies over $\$ 4$ billion a year. ${ }^{9}$ In Germany, the direct psychological effects of workplace violence are estimated to cost over $\$ 112,000$ (U.S.) for every company with 1,000 workers. ${ }^{10}$ The indirect costs are estimated to be around $\$ 58,000$ (U.S.). ${ }^{11}$

In previous work, we argued that a link exists between corporate governance and the reduction of violence. ${ }^{12}$ In this article, we further explore that link focusing on how corporations can work toward the goal of reduction of violence in the societies in which they operate. ${ }^{13}$ Here, we pose the question of how well suited various corporate

${ }^{9}$ Id. at 150.

${ }^{10} \mathrm{Id}$.

${ }^{11} \mathrm{Id}$.

${ }^{12}$ Timothy L. Fort \& Cindy A. Schipani, The Role of the Corporation in Fostering Sustainable Peace, 35 VANDERBILt Journal of TRANSNATIONAL LAW 389 (2000).

${ }^{13}$ See, e.g., Caryn L. Beck-Dudley, Creating a Workplace Where People Can Flourish, 36 VAnD. J. TRAns. L. ___ (2003); Frances E. Zollers \& Eletta Sangrey Callahan, Workplace Violence and Security: Are There Lessons for Peacemaking?, 36 VAND. J. TRANS. L. _ (2003); Dana Muir, Employee Profit Sharing, Voice, and Peace, 36 VAND J. TRANS. L. _ (2003); Terry Morehead Dworkin \& Cindy A. Schipani, Gender Voice and Correlations with Peace, 36 VAnd. J. Trans. L. __ (2003); Thomas W. Dunfee \& Timothy L. Fort, Corporate Hypergoals, Sustainable Peace, and the Adapted Firm, 36 VAND. J. TRANS. L. _ (2003); Tara Radin, The Challenge of Corporate Citizenship, 36 VAND. J. Trans. L. __ (2003); O. Lee Reed, Nationbuilding 101: Property, Liberty, and Corporate Governance, 36 VAND. J. TRANS. L.___ (2003); Michael O'Hara, Governing for Genuine Profit, 36 VAND. J. TRANS. L._ (2003); Thomas Capozolli, Workplace Security: Organizational Model, 36 VAND. J. Trans. L. __ (2003); Lee A. Tavis, Novartis and the United Nations Global Compact, 36 VAND. J. TRANS. L. (2003); Marina von Whitman, Corporate Governance and Sustainable Peace: An Insider's View, 36 VAND. J. Trans. L. ___(2003); Linda Groat, Building Values into Corporate Space, Presentation at 2002 William Davidson Institute Conference, Corporate Governance and Sustainable Peace (November 22-24, 2002); Jane Dutton, Building Compassion Capacity in Organizations as a Pathway for Fostering Peace, Presentation at 2002 William Davidson Institute Conference, Corporate Governance and Sustainable Peace (November 22-24, 2002); Kim Cameron, Organizational Virtuousness and Peace: 
governance regimes are to face these complexities, and how they can cope in ways that are consistent with their fundamental principles. We focus on the corporate governance regimes of the United States, Germany, and Japan. A common denominator of the political entities addressed is a commitment to a political regime of democracy. At least in the post World War II era and particularly in the post Cold War era, all of these countries are committed to democratic governments and principles.

This article is thus organized as follows. Section I outlines our thesis that corporations are in a position to make contributions to peace in society because of shifting political balances of power. Section II analyzes comparative models of

The Case of Forgiveness, Presentation at 2002 William Davidson Institute Conference, Corporate Governance and Sustainable Peace (November 22-24, 2002); Gretchen Spreitzer, Implications of Organizational Leadership and Employee Voice for Peace, Presentation at 2002 William Davidson Institute Conference, Corporate Governance and Sustainable Peace (November 22-24, 2002); Frances J. Milliken, Understanding Dynamics of Voice and Silence in Organizations, Presentation at 2002 William Davidson Institute Conference, Corporate Governance and Sustainable Peace (November 22-24, 2002); Tom McCormick, Ethics and Compliance at Dow, Presentation at 2002 William Davidson Institute Conference, Corporate Governance and Sustainable Peace (November 22-24, 2002); James Walsh \& Joshua Margolis, Misery Loves Company: Whether Social Initiatives by Business? Presentation at 2002 William Davidson Institute Conference, Corporate Governance and Sustainable Peace (November 22-24, 2002); Tara Rangarajan, Defining the Role of the Corporation in Sustainable Peace, Presentation at 2002 William Davidson Institute Conference, Corporate Governance and Sustainable Peace (November 22-24, 2002); Eric Orts, From Corporate Social Responsibility to Global Citizenship, Presentation at 2002 William Davidson Institute Conference, Corporate Governance and Sustainable Peace (November 22-24, 2002); Jeannette Jackson \& Maria Coolican, Strategies for Implementing Organizational Change, Presentation at 2002 William Davidson Institute Conference, Corporate Governance and Sustainable Peace (November 22-24, 2002); C.K. Prahalad, Enabling the Poor to Move into the Market Economy, Presentation at 2002 William Davidson Institute Conference, Corporate Governance and Sustainable Peace (November 22-24, 2002); Susan Finston, The Role of Intellectual Property as Part of a Rule of Law Culture Needed for Economic Growth and Political Stability in the Developing World, Presentation at 2002 William Davidson Institute Conference, Corporate Governance and Sustainable Peace (November 22-24, 2002); George Siedel, The Role of Business Deal Making and Dispute Resolution Processes in 
corporate governance and considers the extent to which contemporary corporate governance models consider peace as a goal they should achieve. Concluding remarks follow in Section III.

\section{The Role of Business and Sustainable Peace}

It can be difficult to understand why corporations are inevitably engaged in issues of building democracy and sustainable peace. Economic imperatives and competitive pressures can seem to make consideration of such political and moral goals beyond the scope of corporate responsibility. Historically, there may be some justification for this reticence, but it is important to see that the twenty-first century may not replicate the geopolitical conditions of the previous several centuries. In large part, this may be due to the balances of power that exist among various institutions including nation-states and multinational corporations, and the relationship corporations have with governments and nongovernmental organizations (NGOs). Thus, this section: (1) addresses the contemporary geopolitical set of conditions that add complexity to the balances of power; (2) delineates the newly emerging alternate forms of democracies that may account for this reality; and (3) articulates various reasons why these alternatives are important to sustainable peace. We then suggest how corporations might foster the stabilizing benefits of democracy, as well as how they might unwittingly undermine those benefits.

\section{A. The Contemporary Context: Balance of Power and the Nation-State}

Contributing to Sustainable Peace, Presentation at 2002 William Davidson Institute Conference, Corporate Governance and Sustainable Peace (November 22-24, 2002). 
Particularly in developed countries, there can be an understandable tendency to think of corporations as private organizations with relatively autonomous authority through state chartering. Under this conception, businesses may act to maximize profits provided they do not violate laws enforced by a typically viable government. There is confidence in this model because, at least in first world countries, governments have the capability to enact and enforce regulations. It is not so clear, however, whether governments of developing countries have the same power vis-à-vis corporations, particularly when considering the transcendence of multinational corporations beyond geographical borders. The comfortable and traditional characterization of corporations as profit maximizers within the confines of the law may not be sufficient in today's world.

A key reason for the concern is the increasing complexity of the world in terms of the number of nation-states that now exist, the proliferation of NGOs, the power of multinational corporations, and perhaps most profoundly, the changing nature of the nation-state. In an ambitious book, constitutional law scholar, Philip Bobbitt, examines the changes in the nation-state throughout history. Bobbitt argues that the construction of legal constitutions has historically resulted from the necessities of war. ${ }^{14}$ Implicit in this argument is that basic legal frameworks rest on balances of power to assure competitive advantage and sustainable peace. As creation of the law, corporations are thus inevitably affected by factors of war and peace.

Bobbitt traces (primarily European) history to describe transitions from princely states to kingly states, territorial states, state-nations, and finally, to nation-states. ${ }^{15}$ The

\footnotetext{
${ }^{14}$ Philip Bobbitt, The Shield of Achilles: War, PeACE, AND the Course Of History (2002).

${ }^{15} I d$. at 215-16. Bobbitt describes the differentiation as follows:
} 
key determinant accounting for each transition was a need to organize society to effectively compete with military advances and challenges. For example, Bobbitt notes that prior to Napolean, most armies were relatively small consisting of fewer than 25,000 men. ${ }^{16}$ Armies were professional and therefore expensive, so warfare was largely about avoiding their destruction. ${ }^{17}$ Napolean, was an exception in his desire to create clashes in opposing countries to break morale and ultimately induce them to surrender extant economic resources. ${ }^{18}$ The French Revolution, however, gave rise to popular involvement in politics and Napolean, by 1794, took advantage of popular passion to create massive armies of almost 1.2 million men which, although untrained, were able to overwhelm smaller, professional armies. ${ }^{19}$

Warfare required popular sacrifice, and therefore required a different kind of political apparatus as well as more detailed laws to describe the basis for government,

The princely state promised external security, the freedom from domination and interference by foreign powers. The kingly state inherited this responsibility and added the promise of internal stability. The territorial state added the promise of expanding material wealth, to which the state-nation further added the civil and political rights of popular sovereignty. To all these responsibilities the nationstate added the promise of providing economic security and public goods to its people. The failure of the Soviet Union to live up to this expectation, as much as any other cause, contributed to its delegitimation in the eyes of its nation. Very simply, the strategic innovations of the Long War will make it increasingly difficult for the nation-state to fulfill its responsibilities. That will account for its delegitimation. The new constitutional order that will supercede the nation-state will be one that copes better with these new demands of legitimization, by redefining the fundamental compact on which the assumption of legitimate power is based.
${ }^{16} \mathrm{Id}$. at 162 .
${ }^{17} \mathrm{Id}$. at 187 .
${ }^{18} \mathrm{Id}$. at 187.
${ }^{19}$ Id. at 175. 
taxation, and conscription. ${ }^{20}$ Thus, while Napolean is known for his military characteristics of ambitious and strategic innovation, he is also famous for his ability

to obligate the mass of persons to the French state. Among this vast people various groups from the bourgeoisie were employed in the service of the state; for their members there were lower taxes extracted by France from her conquered neighbors; working men found in the state an employer of last resort - the army (whose mass employment would not have been possible under the strategic and tactical constraints of the armies of the territorial state); and for every class a new meritocracy arose that measured status according to services rendered to the State. ${ }^{21}$

According to Bobbitt's thesis, this example is one of law relating to military strategy and military strategy to law, because they mutually reinforce the state's capacity for warfare. $^{22}$

In the twentieth century, this relationship manifested itself in the nation-state, which Bobbitt argues, drew its legitimacy (a core concept necessary to any state), from its ability to satisfy the welfare of the constituents it governed and from whom it demanded sacrifices. ${ }^{23}$ Coming out of World War I, there were three contenders for the nation-state system that would best accomplish constituent welfare: fascism, communism, and parliamentary democracy. ${ }^{24}$ Bobbitt views the era of 1914-1990 as "The Long War" fought to settle which of these alternatives best benefited the welfare of citizens with parliamentary democracy successively defeating fascism (in World War II) and communism (in the Cold War). ${ }^{25}$ Yet, the conclusion of each "epochal war" also brings with it a new set of challenges. Out of the Long War, Bobbitt argues that a new kind of

\footnotetext{
${ }^{20} I d$. at 175 .

${ }^{21} I d$. at 539.

${ }^{22}$ Id. at 5-17.

${ }^{23} \mathrm{Id}$. at 5-6.

${ }^{24} I d$. at 24-25.

${ }^{25} I d$. at 24-64.
} 
state is emerging - the market state - whose legitimacy is not based on providing welfare for its citizens (particularly in the form of welfare entitlements, pensions, etc.) but whose rasion d'etre is to provide opportunities for its citizens through market opportunities and education. ${ }^{26}$ These opportunities allow individuals to participate and to compete effectively in a global economy. This environment recognizes the proliferation of nongovernmental powers, which although undermining the traditional nation-state, insist on respect for human rights regardless of the nation-state's historical stand. It further recognizes the increasing power of multinational corporations that may provide economic opportunity regardless of the nation-state's traditional economic regulations. ${ }^{27}$

Bobbitt describes three models that describe the way these market states are taking shape. They are they U.S. model, the German model, and the Japanese model. More will be said about the specific governance regimes these models reflect. If Bobbitt is correct, the question becomes whether there is a way for these market-state systems to evolve so that they may: (1) confront violent threats to them collectively (as through challenges from terrorism or from non-democratic regimes) and (2) provide economic innovation, shaped through law, to make key border-crossing institutions, such as multinational corporations, instruments of sustainable peace.

\section{B. The Parliamentary Models: Germany, Japan, and the U.S.}

In general, democracies operate according to the wishes of a body of citizens electing representatives to govern them. In Spencer Weart's historical analysis, a

\footnotetext{
${ }^{26}$ Bobbitt, supra note 14, at 222 (citing in particular the UK policies of Tony Blair as well as the U.S. policies).

${ }^{27}$ Id. at $229-29$.
} 
democracy is defined first in terms of a republic. ${ }^{28}$ A republic's defining feature is that "political decisions [are] made by a body of citizens who have equal rights." ${ }^{29}$ Such decisions are those made in light of "public contestation" of choices with political officials, who are accountable to the citizens for their actions. ${ }^{30}$ To have public contestations, there must be free political expression, rule of law, and toleration of politically dissenting minorities. ${ }^{31}$ The exact implementation of these features can vary significantly. Weart also differentiates between oligarchic republics and democratic republics. An oligarchic republic features voting by only one-third of citizens whereas democratic republics feature voting by two-thirds of citizens. ${ }^{32}$ Interestingly, oligarchic republics rarely make war on other oligarchic republics and, according to Weart's analysis, democratic republics never make war on other democratic republics. ${ }^{33}$

The specific characteristics of equal rights, toleration of dissent, voting, and free expression suggest that there is a different character of political solidarity in a democracy than might exist in other kinds of political regimes. Indeed, at the heart of Weart's analysis of republicanism is the idea of political culture. ${ }^{34}$ A republican political culture,

\footnotetext{
${ }^{28}$ Spencer R. Weart, NeVer at War: Why Democracies Will Not Fight One ANOTHER 11 (1998).

${ }^{29}$ Weart, supra note 28 , at 11.

${ }^{30} \mathrm{Id}$.

${ }^{31} I d$. Actually, this designation of democracy has been applied to situations where twothirds of men vote. While there are historical reasons to accept and normative reasons to support this as good, it may be desirable to think more broadly of citizenship as democracies developed in the twentieth century with increased universality of suffrage. ${ }^{32}$ Weart, supra note 28 , at 12.

${ }^{33} \mathrm{Id}$. at 14 . Weart provides a caveat that these republics must be "well-established." By this, he means that toleration of dissent has persisted for at least three years. Id. at 21 . $\mathrm{He}$ indicates that the differentiation feature between oligarchic and democratic republics is that oligarchic republics suppress a "crucial domestic enemy" whereas democracies are more embracing of them. Id. at 18.

${ }^{34}$ Id. at 15 .
} 
and particularly a democratic political culture not only embraces ideas of equal rights, public contestation, and toleration of political dissent, but it also values the political process and resolves disputes among citizens by negotiation and mutual accommodation rather than by coercion. ${ }^{35}$

Benjamin Barber builds upon similar notions when he argues that democracy requires the foundation of civil society. ${ }^{36}$ This foundation is not built quickly as the evolution of democracy in Britain and the United States shows, but rather slowly; nearly three quarters of a millennium passed between Magna Carta to the Declaration of Independence. ${ }^{37}$ Although, as Barber argues, civil society is not about voting and buying and selling, it is about an environment "where we talk with neighbors about a crossing guard, plan a benefit for our community school, discuss how our church or synagogue can shelter the homeless, or organize a summer softball league for our children." 38 Civil society, therefore, provides a foundation for democracy because it trains people to organize themselves to solve public issues in a non-coercive way, on the basis of respect, persuasion, and negotiation -- the hallmarks of a republic political culture. These activities are not about political organizing as much as they are about being part of a small group within which individuals are empowered to affect the norms of the community, or what is also known as a mediating institution. ${ }^{39}$ These activities and institutions are "public" just as the government is public, but they "make no claim to

${ }^{35}$ See id. (the designation of these features being particularly prevalent in democracies is the authors' addition to Weart's argument).

${ }^{36}$ BENJAMin R. BARBER, JiHAd vs McWorld: How Globalization AND TRIBALism ARE RESHAPING THE WORLD 276 (1995).

${ }^{37}$ See id. at 278 .

${ }^{38}$ Id. at 281 . 
exercise a monopoly on legitimate coercion." ${ }^{40}$ That is, mediating institutions do not seek merely their own self-advancement as a for-profit corporation might, but instead, they are concerned with issues concerning the common good. ${ }^{41}$

There is a direct link to peace resulting from such societies because leaders who deal with equals at home by non-coercive negotiation and compromise and are likely to deal with other similarly-inclined leaders of other nations through negotiation and compromise. $^{42}$ This does not mean that democratic (or oligarchic republican) cultures are incapable of warfare; but rather that they do not engage in warfare with similar kinds of political cultures. $^{43}$ Thus, democratic societies can be defined by the particular features of public contestation, equal rights, free expression, negotiation, compromise, election of representatives and accountability of those representatives to voters. Underlying those societies is civil society where people voluntarily engage in quests for public goods that define their mediating institutions, but which also reach beyond special interests to embrace the common good.

This kind of political system has, according to Bobbitt, defeated fascism and communism in the epochal war he calls "The Long War" that lasted from 1914 to $1990 .{ }^{44}$ Yet, with the end of The Long War, the creation of market-states poses new kinds of variations for optimal organization. What is particularly significant is how all three

39 See, Peter Berger \& Richard John Neuhaus, To Empower People (1977) (noting that in small, mediating structures, human beings find their public face).

${ }^{40}$ Barber, supra note 36, at 281.

${ }^{41}$ Id.

${ }^{42}$ Weart, supra note 28 , at 16.

${ }^{43} \mathrm{Id}$. at $16-17$

${ }^{44}$ Bobbitt, supra note 14, at 24. 
variations - the German, Japanese, and U.S. model - provide for a system where economic transactions of multinational corporations have a central role.

As noted above, Bobbitt has coined the term "market-state" to describe a new kind of state that is emerging. Bobbitt argues that market-states make the maximization of opportunities for citizens the basis of their legitimacy. ${ }^{45}$ But each differs according to how it creates those opportunities. In the United States, it means

providing infrastructure (including intangible infrastructure like education and the means of enforcing agreements) and relying on private enterprise to maximize the abundance of consumer choice and minimize the costs to the consumer of exercising choice. In Tokyo, by contrast, maximizing opportunity means protecting domestic industries so that future generations will have a full array of employment opportunities, subsidizing research and development so that future opportunities for innovation will be practicably exploitable, and restricting the import of capital so that the government remains in control of its capital allocation. In Berlin, maximizing opportunity means social and economic equality among citizens so that opportunities available to communities, workers and future generations are maximized rather than maximizing the shortterm profits of shareholders. ${ }^{46}$

Bobbitt characterizes the differing models used by democracies as: (1) the Entrepreneurial Model; (2) the Mercantile Model; and (3) the Managerial Model.

The "Entrepreneurial Model," which Bobbitt uses to characterize the U.S. approach, but which is not used exclusively by the U.S., is a model that stresses autonomy, individual achievement and consumption that "citizens of these states 'invent' their citizenships, identifying themselves with those subgroups within the state with whom they share a consumption pattern." ${ }^{\text {47 }}$ Labor relations in this model tend to be

\footnotetext{
${ }^{45} I d$. at 669.

${ }^{46} \mathrm{Id}$.

${ }^{47}$ Id. at 670 .
} 
confrontational and immigration is generally welcomed. ${ }^{48}$ Thus, the Entrepreneurial Model is more libertarian, less socially cohesive, with protections of citizens coming more from media exposure of wrongdoing than from government. ${ }^{49}$ This, however, exacerbates the problems of social cohesion that every market-state faces.

This model also stresses guarantees for human rights, free press, and political dissent, which tend to support individualism. The Entrepreneurial Model has proponents outside of the English-speaking world, including, for example, Thailand and Peru. ${ }^{50}$

In the "Mercantile Model," which Bobbitt uses to characterize the Japanese approach, but which is not exclusively used by the Japanese, immigration is discouraged in favor of maintaining "cultural homogeneity," and labor relations tend to be more familial. ${ }^{51}$ This model also "retain[s] conscription for military service (though with force levels vastly reduced from those of the twentieth century), affirmative action for certain social groups, and varying degrees of state control of the media." ${ }^{, 52}$ The Mercantile Model provides that human rights are more communitarian rather than individualistic and that "harmony rather than division" and "respect and reverence are a truer expression of its cultural values." 53 These states, therefore, "attempt to minimize the public expression of opposition." 54

Finally, Bobbitt's third model, the "Managerial Model," characterizes the German approach, although not exclusively German. This model also retains conscription for

\footnotetext{
${ }^{48} I d$. at 671.

${ }^{49} \mathrm{Id}$. at $670-71$.

${ }^{50} \mathrm{Id}$. at 675 .

${ }^{51} \mathrm{Id}$. at 671 .

${ }^{52} \mathrm{Id}$. at 670 .

${ }^{53} \mathrm{Id}$. at 675.

${ }^{54} I d$.
} 
military service, affirmative action, and some control of the state media. ${ }^{55}$ With regard to labor relations, the Managerial Model “is ambivalent: open to 'guest workers' but hostile to new citizens.",56

From the snapshots of these models, predictions can be made about some of the salient features of corporate governance systems these models would promote. The Entrepreneurial Model would stress agility subject to free choices. Thus, an underpinning legal infrastructure of this model would stress transparency, fluid labor movement, and a predominant emphasis on protecting investment capital. Indeed, these are features of the U.S. model. Yet, the 2002 corporate scandals demonstrate that this model also runs great risks of insufficiently accomplishing its goals. In 2002, the country found that corporate executives and boards could be opaque rather than transparent with devastating effects for investors as well as employees.

The Mercantile market-state typically has a strong central government that partners with business concerns in order to enhance national industries and subsidize crucial research and development while deemphasizing consumption. ${ }^{57}$ Social cohesion is maintained by suppressing income disparities and subsidizing public housing and access to education with the important proviso, according to Bobbitt, that these benefits are available only for those who are eager to work. ${ }^{58}$ Mercantile market-states, such as Singapore, Hong Kong, Taiwan, and South Korea, have had impressive growth although

${ }^{55}$ Id. at 674

${ }^{56} \mathrm{Id}$. at 671.

${ }^{57} \mathrm{Id}$.

${ }^{58} I d$. 
their efficiency and productivity levels are more in the range of Egypt, Greece, Syria, and Cameroon. $^{59}$ Thus, the Mercantile Model faces the challenges of

opening up domestic markets to foreign competition; reforming the banking sector to bring greater scrutiny to credit transactions; allowing access to cheaper credit for smaller firms that are usually restricted to relatively high priced domestic finance and letting the cost of capital to dominant firms rise...the Korean Model is characterized by the concentration of power in four great companies (Samsung, Hyndai, Lucky-Goldstar, and Daewoo)...In Japan, the largest six companies account for over half the total assets of all listed enterprises. Furthermore, some three-quarters of all shares are mutually held between companies and their financial institutions. ${ }^{60}$

From this, it can be predicted that the Mercantile Model will encourage a corporate governance system that is less concerned with transparency and its concomitant fluidity and more focused on social cohesion. In such a system, one would expect tight, opaque control of capital with an offsetting corporate culture stressing loyalty to a corporate community. Indeed, these are features of this model. Yet, the 1990s show that this model also brings with it significant limitations on creativity and growth, which can undermine the corporate goals. Lifetime employment may not be achievable under this system and capital investment returns may be dampened.

The Managerial market-state, according to Bobbitt, "consists of three basic elements: free and open markets within a regional trading framework, a government that provides a social safety net and manages a stringent monetary policy, and a socially cohesive society." ${ }^{, 61}$ Protections are provided for ownership of private property but such

\footnotetext{
${ }^{59}$ Id. at 672.

${ }^{60} \mathrm{Id}$.

${ }^{61} I d$. at $672-73$.
} 
ownership also must contribute to the public good. ${ }^{62}$ Labor and management are required to share power on corporate boards. ${ }^{63}$ This system creates the "stakeholder company," that attempts to balance all the actors affected by a corporate action, although corporate ownership is typically closely held through a centralized commercial bank. ${ }^{64}$ Bobbitt describes the goal of the Managerial Model as being that of social equality whereas the goal of the Mercantile Model of social stability. Government intervention tends to be more aligned with labor in the Managerial Model as opposed to capital in the Mercantile Model. ${ }^{65}$ Although cohesion is also as important for the Managerial Model as it is for the Mercantile Model, the states following the Managerial Model, according to Bobbitt, tend to pay productive workers well and provide generous welfare benefits for those who do not have a job. ${ }^{66}$ Beyond Germany, practitioners of the Managerial Model include India, Turkey, and Egypt. ${ }^{67}$

It follows that corporate governance regimes under a Managerial Model would encourage long-term goals of justice, consensually endorsed notions by the affected stakeholders. This system would be fortified by equipping stakeholders, particularly employees, with power to influence decisions. In fact, this is a hallmark of the Managerial Model. Yet, this approach also limits creativity and, paradoxically, limits the influence of actors that could be affected because the number of actors is so large that a delegation of responsibility is inevitable. Thus, it is questionable whether this model can achieve its goals.
${ }^{62} \mathrm{Id}$.
${ }^{63} \mathrm{Id}$.
${ }^{64} \mathrm{Id}$.
${ }^{65} \mathrm{Id}$.
${ }^{66} \mathrm{Id}$. at 674. 
Admittedly, there is not a "perfect" system -- any organizational and political theory will carry with it contradictory elements. Yet, there are at least three reasons for why each model needs to be open to influences from one another as well as to those other models that attempt an overarching synthesis.

First, each model is potentially a target of terrorism. For example, Japan suffered from attacks via sarin gas and the U.S. suffered via the attacks of September 11, 2001. If a sense of justice mitigates some of the passions that might trigger such an attack, then each system needs to consider how to mitigate its weaknesses. This is not to argue that mitigating weaknesses will prevent terrorism or that the weaknesses caused terrorism. It is hard to see, for instance, how the better enforcement of generally accepted accounting principles and Securities and Exchange regulations had anything to do with the horrific events of September 11. Yet, improving the perception of the justness of capitalism and democracy may help moderate social frustration.

Second, each model contains concerns for its own constituents. As Bobbitt argues,

each model must contend with its own sort of alienation: the lowest paid workers in the United States are vastly worse off than high wage earners, while the unemployed in Europe can get by on welfare benefits alone but have little prospect of a job. By contrast, the Mercantile Model maintains artificially high employment rates, at wages that reflect far less disparity between the highest and lowest paid. The unavoidable cost is in productivity and efficiency, which sets the stage for a new kind of alienation, that of the young from the old. ${ }^{68}$

Finally, the framework implicit in this tri-partite delineation is that in order to prevent the models from becoming too ideological and competitive, "it is to be hoped

${ }^{67}$ Id. 
that informal private networks that cross international lines - for example, the large multinational corporations developed in the twentieth century, or the extensive social networks developed by overseas Chinese in East Asia and the United States, or global nongovernmental organizations - will supply the links necessary to prevent the growing divergence of the three models of the market-state."69

The next question is how will this be accomplished. Given the realities that the major governing paradigms are variations of democracy, it seems appropriate to examine what benefits democracy itself may offer and how corporations interact with democratic institutions.

\section{Benefits of Democracy}

Immanuel Kant thought that free peoples were inherently peaceful. ${ }^{70}$ The historical record, however, is mixed; democracies can be as warlike as any other regime. ${ }^{71}$ Yet, the fact remains that democratic countries do not fight each other. Spencer Weart reviews historical data and establishes the claim that "well-established democracies have never made war on one another."72 Corroborating that claim, Babst studied wars fought since 1500 and found no wars (involving at least 50,000 troops or fought to cause territorial transfer, a change in government, or eradication of a state) had occurred between freely elected, independent governments. ${ }^{73}$ Three reasons have been offered for why this is true.

${ }^{68} \mathrm{Id}$. at 675.

${ }^{69} \mathrm{Id}$.

${ }^{70}$ See Weart, supra note 28 , at 3.

${ }^{71} I d$. at 3.

${ }^{72} \mathrm{Id}$. at 13 .

${ }^{73}$ Dean V. Bapst, A Force for Peace 55 Industrial Research (Apr. 1972). 
First, democratic republics are more pluralistic than authoritarian regimes. ${ }^{74}$ The mediating institutions that proliferate in civil society cut across various social ties so that no one group's anger can automatically lead to belligerence. ${ }^{75}$ The multiple ties any one person might feel toward a particular neighborhood, church, or political party create an internal check on political processes and make it more difficult for a central authority to claim the need to go to war to vindicate the interests of a particular group. ${ }^{76}$

Second, Weart writes that the theory "that republicans generally behave more peacefully toward other nations than do autocrats has been confirmed about as reliably as anything can be in statistical studies of human communities." ${ }^{, 77}$ In a democracy, a leader has little choice but to compromise and this leadership style tends to extend to those outside of one's borders assuming that a preference for negotiation also exists on the other side. ${ }^{78}$

In order for Weart to make his argument about the benefits of democracy vis-à-vis peace, he creates a few basic definitions. These definitions are helpful in beginning the process of transferring democratic principles over to a corporate context. Weart argues that what makes a culture republican is equal rights among citizens and the toleration of

\footnotetext{
${ }^{74}$ Weart, supra note 28 , at 44.

${ }^{75} \mathrm{Id}$. at 44 .

${ }^{76} \mathrm{Id}$.

${ }^{77} \mathrm{Id}$. at 89 .

${ }^{78} \mathrm{Id}$. at 90 . Although the first two reasons why democratic governments do not engage in conflict with each other characterize democratic countries are in terms of pluralism and compromise, the third reason is not so flattering. Weart argues that a country that is not republican can be characterized by a democratic republic as an "outgroup" that is "inherently treacherous and aggressive." There is an extensive literature demonstrating that violence often accompanies the characterization of another group of people as an "outgroup." Thus, it is important to recognize that democratic republics are not themselves more peaceful, but they may be more peaceful toward like-minded political regimes. See id., at 90.
} 
dissent. ${ }^{79}$ Moreover, a culture does not become an established republic simply by a declaration; instead, to meet this classification, toleration of dissent must have persisted for at least three years. ${ }^{80}$

Thus, one way businesses might be able to contribute to peace is to support the establishment of democratic regimes wherever they do business. This would require more than rhetoric, it would also require support of equal rights and tolerance of dissent. Even if a corporation cannot nudge a political regime toward democracy, it can implement some of the practices which define a democracy in its own governance structure. By doing so, it may well provide a model for democratic-like attributes that could spillover into the political culture and nourish experiments in democratic decision-making. ${ }^{81}$

\section{The Role for the Corporation}

\section{The Paradox of Globalization and Democracy}

Benjamin Barber has argued that democracy is under attack from two very different sources. One source is Jihad, which typically is thought in terms of Islamic extremism, but which Barber argues is a metaphor for all parochial groups reacting against globalization. ${ }^{82}$ The other source is McWorld, which transcends traditional

\footnotetext{
${ }^{79}$ Weart, supra note 28 , at 15.

${ }^{80} \mathrm{Id}$. at 20.

${ }^{81}$ Fort \& Schipani, supra note 12, at 434 (noting anthropological studies of peaceful societies which have characteristics of face-to-face interaction, non hierarchical decision making, gender equity, being relatively small in population, an the practicing of nonviolent dispute resolution).

${ }^{82}$ BARBER, supra note 36.
} 
borders and boundaries to link people together in a quest for consuming goods and achieving profitability. As different as they are:

Jihad and McWorld have this in common: they both make war on the sovereign nation-state and thus undermine the nation-state's democratic institutions. Each eschews civil society and belittles democratic citizenship, neither seeks alternative democratic institutions. Their common thread is indifference to civil liberty. ${ }^{83}$

Barber argues that Jihad is committed to bloody politics of identity whereas McWorld is a bloodless pursuit of profitability. ${ }^{84}$ Jihad reacts against the homogenization of culture by fighting global business and, as Barber makes clear, Jihad's disdain is more with capitalism than it is with democracy. ${ }^{85}$ McWorld has little argument with democratic institutions, but undermines the community ties necessary for individuals to understand their connection to the common good as opposed to a market where self-interest only is the necessary consideration. ${ }^{86}$ Moreover, the "twin assault on democratic citizenship from the fractious forces of Jihad and the spreading markets of McWorld in effect undercuts democratic institutions." ${ }^{87}$ The paradox is that corporations thrive on democratic virtues, but simultaneously undercut them. ${ }^{88}$

${ }^{83} I d$. at 6 .

${ }^{84} \mathrm{Id}$. at 8 .

${ }^{85} \mathrm{Id}$. at 20 .

${ }^{86} \mathrm{Id}$. at 243.

${ }^{87}$ BARBER, supra note 36 , at 219.

${ }^{88}$ WEART, supra note 28, at 81 . Economist Jane Jacobs, for instance argued that she could divide political beliefs into two categories in which one focused on hierarchy, discipline, obedience, and vengeance and the other focused on collaboration, negotiation, avoiding force and respecting contracts. These commercial virtues seem similar to republican virtues, but present a series of issues. Can commerce thrive without stability? More deeply, if respect for contracts and property is a central requirement for capitalism to flourish, is not the market dependent upon things like the rule of law, which arises in a manner more complex than via economic rationality? And if stability and the rule of law 
In response to this paradox, Barber claims that one must rebuild civil society, including the traditional mediating institutions that bridge commonly made distinctions between public and private life. Barber argues that we too often rely on a "two-celled" distinction between government versus private sector, but the middle ground of civil society is where we voluntarily come together to talk about what is necessary for the common good, be it the softball league, religious outreach, or neighborhood crossing guards. ${ }^{89}$ Unlike governmental affairs, there is no coercion present - actions are voluntary - but unlike the private sector, there is concern for the common good. ${ }^{90}$ It is in this realm, a realm Barber argues is populated by schools, churches, public interest groups, and other civic organizations, where citizenship is developed. ${ }^{91}$ That space, however, has been squeezed, he argues, as corporations encroach on the space of civil society, as governments react to check the rise of corporate power, and as individuals begin to think of themselves as consumers rather than citizens. ${ }^{92}$

Barber's analysis begs the question whether business is part of civil society. Barber suggests that the answer is no, noting that it may be unfair to ask a corporation to be committed to a vision of justice or democracy. ${ }^{93}$ He argues, however, that businesses wade into political issues if only to create a middle class that can purchase their goods. Businesses, he argues, are not designed to do what democratic polities do

are nourished by democratic virtues, then what does one do if markets undermine notions of citizenship? See BARBER, supra note 36, at 14.

${ }^{89}$ BARBER, supra note 36, at 281.

${ }^{90} \mathrm{Id}$.

${ }^{91} \mathrm{Id}$.

${ }^{92} \mathrm{Id}$. at $282-283$.

${ }^{93}$ Id. at 282. 
- they are contractual rather than communitarian. ${ }^{94}$ Yet, this account misses two important points.

First, although markets may not be designed to create democratic polities, businesses draw people to work for them and invest in them, usually on a voluntary basis. In doing so, they require people to work together for a common good, even if that good is simply profitability. Profitability does not occur without significant practices of human cooperation within the organization. Thus, businesses have the essential features Barber recognizes as emblematic of civil associations.

Second, Barber follows Edmund Burke in arguing that human solidarity is formed by "resemblances, by conformities, by sympathies" rather than by contracts. ${ }^{95}$ Yet, experimental psychological testing shows that association can be as arbitrary as whether a person has a dot on a nose or not. ${ }^{96}$ In other words, human solidarity is not trapped by ethnic, religious, or genetic characteristics, but by any kind of affiliation, which could include people of differing ethnic origins working together. The so-called private sector is not as private as one might think and within a business organization lies the potential, even the necessity, for working together for some common good. Thus, while Barber argues that the reinvigorization of a variety of mediating institutions in society would be worthwhile, we also emphasize that business institutions themselves possess resources for encouraging individuals to exercise voice in working for a common good. The freedom to exercise voice entails a need to tolerate dissent;

\footnotetext{
${ }^{94}$ Id. at 242.

${ }^{95} \mathrm{Id}$.

${ }^{96}$ See David M. Messick, Social Categories \& Business Ethics, 1 Bus. ETHICs QuART. (Special Issue: Ruffin Series) 149 (1998) (explaining that the arbitrary selection of who
} 
otherwise only a narrow range of voices will be heard. Within this exercise of voice and toleration of dissent lay the seeds for a business organization to foster a sense of democracy within its own borders. This does not mean that businesses always or even frequently actualize this potential. Yet, the potential is there, governance regimes are not far from supporting that actualization, and the steps necessary to actualize that potential lie in a commitment of business to peace. That commitment not only breeds the stability on which business thrives, but also lays the groundwork for democratic republics to rise. If multinational corporations in democratic countries do this, they may have provided a way to overcome challenges raised against them by appealing directly to the source of democratic liberal tradition.

\section{The Huntington Thesis and the Spillover Effects of Corporate Behavior}

In his book, The Clash of Civilizations, Samuel Huntington, like Bobbitt, argues that the end of the Cold War has triggered a new balance of power among state actors. ${ }^{97}$ The Cold War, he argues, was able to submerge the ambitions for nationhood desired by a variety of ethnic groups but without the bi-polarity of Soviet-U.S. competition, so that these groups now have a freer reign to pursue goals of creating their own nation-states. ${ }^{98}$ These desires are not new, but the desire to bring all ethnic cousins under one state may spark terrible conflicts including, at the extreme, ethnic cleansing. ${ }^{99}$ Huntington argues that the world will increasingly organize itself along these lines of identity rather than

belongs in an in or an out group is such that the division could be contractual rather than one based on Burke's sense).

97 SAmuel Huntington, The Clash of Civilizations (1996).

${ }^{98} I d$. at $20-29$.

${ }^{99}$ Id. at 21. 
nation-state status. ${ }^{100}$ Thus, the world will tend to be grouped in terms of North American, South American, European, Russian, Muslim, Indian, African, Chinese, and Japanese peoples. ${ }^{101}$ As the 1990s Balkans conflicts demonstrate, however, this means that not only might there be nation-states in conflict with each other, but because regions contain differing ethnic groups, there will also be potential for internal as well as external conflict. $^{102}$ Because Muslims in Egypt might identify with Muslims in Bosnia and Russians might identify with Slavs in Serbia, internal conflict can also exacerbate severe external tensions. $^{103}$

The location of ethnic linkages around the world is nothing new. The Balkans have long struggled with this problem and the presence of Germans outside of Nazi Germany was one of Hitler's pretexts for triggering World War II. More benignly, China considers someone of Chinese heritage (such as an adopted child) as Chinese with an assumed identification with the Middle Kingdom ${ }^{104}$ and the Czech Republic allows its president to be someone of Czech origin, even if not a "citizen."105 Globalization, however, fosters additional immigration and immigration may further engender domestic conflicts in the countries to which the immigrants locate. It may also spark conflicts between the immigrants' home and new countries, if it is perceived either that the emigrees are not being treated well or, alternatively, that the emigrees are undermining the new country's identity.

\footnotetext{
${ }^{100} \mathrm{Id}$. at $32-33$.

${ }^{101} \mathrm{Id}$. at 36.

${ }^{102}$ Id. at 272-91.

${ }^{103}$ Huntington, supra note 97, at 126-27.

${ }^{104}$ See, id. at 129 (noting the differences with which Chinese treat Chinese foreigners and non-Chinese foreigners).
} 
Finally, this has implications for governments. Bobbitt argues that governments that are able to successfully adapt to new global conditions are not only successful, but are duplicated by others. ${ }^{106}$ As we have seen, he notes the prevalence of powerful parliamentary democracies practiced by the United States, Germany, and Japan as three distinguishable models. ${ }^{107}$ If it is true that democracies are more prone to resolving disputes nonviolently, at least vis-à-vis other democracies, it may be important for corporations to engage in practices that contribute to democracy to foster a system that is more nonviolent than authoritarian alternatives, and to provide a model for countries to emulate. This, in turn, may reinforce commitments to both democracy and sustainable peace.

The "market-states" of the democratic, liberal tradition are in the position to engage in the creation of models that link the world both through democratic principles and through economic enterprise but are also in the position to re-create rivalries. To avoid the problems Benjamin Barber finds endemic to capitalism and inimical to democracy, multinational corporations and the states that authorize their existence through requisite governance regimes, must consider how corporate behavior can enhance rather than undermine the democratic basis on which they are formed.

To make this argument more concretely, we engage in an analysis of leading, extant corporate governance frameworks in the United States, Germany, and Japan. These countries account for over $50 \%$ of the world's gross product, and if there is to be leadership in corporate governance along the lines we propose, it will be through these

105 This is why former Secretary of State, Madeleine Albright was offered the presidency of the Czech Republic.

${ }^{106}$ Bobbitt, supra note 14, at 67. 
countries. The universe of the largest corporations of the work is primarily population by firms belonging to one of these three economies. ${ }^{108}$ Moreover, the governance systems of Germany, Japan and the United States have substantial spillover effects beyond their

respective borders. ${ }^{109}$ Many countries in Europe, such as Austria, Belgium, Hungary, and to a lesser extent, France and Switzerland, and much of Northern Europe evolved their governance systems along Germanic, rather than Anglo-American lines. ${ }^{110}$ The spillover effects are also evident in Asia, where Japanese firms have been the largest direct foreign investors during the past decade. ${ }^{111}$ Variants of the Anglo-American system of governance are evident in countries such as the United Kingdom, Canada, Australia, and New Zealand. ${ }^{112}$ Given these significant spillover effects, it becomes important for these models to evolve in such a way so that they may confront violent threats to them collectively, and provide economic innovation to make them instruments of sustainable peace. The following section considers the current regimes.

\section{Implications for Corporate Governance}

Corporate governance has been defined as a top management process, that when operating correctly, should manage value creation and value transference among various corporate claimants in a way that ensures accountability toward those

${ }^{107}$ See supra notes 26-69 and accompanying text.

${ }^{108}$ Michael Bradley et al., The Purposes and Accountability of the Corporation in Contemporary Society: Corporate Governance at a Crossroads, 62 LAW \& CONTEMP. PROBS. 9, 51 (1999).

${ }^{109} I d$.

${ }^{110} \mathrm{Id}$.

${ }^{111} \mathrm{Id}$.

${ }^{112}$ Id. 
claimants. ${ }^{113}$ Claimants can be broadly defined to include all of those with a stake in corporate operations, including shareholders, customers, employees, suppliers, creditors and the local community. ${ }^{114}$ This definition emphasizes both efficiency and fairness.

There are different ways to approach issues of corporate governance. In the United States, dating at least back 1919 in the famous case of Dodge v. Ford, ${ }^{115}$ the approach has been a model that has focused primarily on the shareholder, the residual claimant of the corporate form. In Dodge v. Ford, the court specifically stated that a "business corporation is organized and carried on primarily for the profit of the stockholders." 116 In other regimes, such as Germany and Japan, the interest of society and employees have historically, been the first focal point. All three regimes have had both prosperous as well as trying times.

This section examines these three models in the context of a search for incorporating the goal of peace into local corporate governance thinking. Although all models, in some way or another, consider interests of various constituencies, including society at large, these models do not focus on the goal of peace itself as a general aspiration. We propose that consideration of peace as a goal is not a far stretch from what the regimes are already doing, and has the potential for far-reaching effects not only for society at large, but also for business itself.

\section{A. Corporation Governance Regimes of Competing Market-State Models}

\footnotetext{
${ }^{113}$ Timothy L Fort \& Cindy A. Schipani, Corporate Governance in a Global Environment: The Search for the Best of All Worlds, 33 VANDERBILT J. TRANSN'L L. 829, 832 (2000); Bradley et al., supra note 108, at 61.

114 See, e.g., Fort \& Schipani, supra note 113, at 833; Bradley, et al., supra note 108, at 11.

${ }^{115}$ Dodge v. Ford, 170 N.W. 668, 684 (Mich. 1919).

${ }^{116}$ Id. at 684 .
} 


\section{The U.S. Model}

First and foremost, throughout U.S. history, corporate governance has focused on the rights of shareholders. The concern in the United States has been fear that because of separation of ownership from control that exists there is the possibility that management will act in its own self-interest to the detriment of the firms' owners. As such, the law has imposed fiduciary duties on corporate officers and directors, such as the fiduciary duties of care and loyalty. ${ }^{117}$ The fiduciary duties are said to run to the corporation and its shareholders. ${ }^{118}$ These duties require corporate officers and directors to exercise the degree of care in the conduct of corporate affairs as the reasonably diligent person would in similar circumstances, as well as to act in good faith and in the "honest belief that the action taken is in the best interests of the corporation."119 They also require officers and directors to put corporate interests ahead of personal interests, in other words, to avoid conflicts of interest. ${ }^{120}$ The emphasis on fiduciary duties and relationships indicate that shareholder protection is a paramount objective expressed in the legal realm of corporate governance. ${ }^{121}$

The U.S. model is, however, multi-faceted. According to the American Law Institute (ALI) Principles of Corporate Governance, even if corporate profit is not enhanced, corporations may also take into account "ethical considerations that are

${ }^{117}$ See, e.g., Michael Bradley \& Cindy A. Schipani, The Relevance of the Duty of Care Standard in Corporate Governance, 75 IowA L. REV. 1 (1989).

${ }^{118} \mathrm{Id}$.

${ }^{119}$ Balotti \& Gentile, Commentary from the Bar, Elimination or Limitation of Director Liability for Delaware Corporations, 12 DEL. J. CORP. L. 5, 14 (1987); Bradley \& Schipani, supra note 117, at 25.

${ }^{120}$ Bradley \& Schipani, supra note 117 , at 25.

${ }^{121}$ AMERICAN LAW INSTITUTE, PRINCIPLES OF CORPORATE GOVERNANCE: ANALYSIS AND RECOMMENDATIONS, Section 2.01 (1994). 
reasonably regarded as appropriate to the responsible conduct of business."122 A corporation may attain this objective by "devot[ing] a reasonable amount of resources to public welfare, humanitarian, educational, and philanthropic purposes."123 Most states endorse this position, which retreats from the position of shareholder primacy to the exclusion of all other interests, by statutorily permitting corporations to take into account the interests of stakeholders, other than shareholders, when making corporate decisions. The New York statute, for example, expressly provides that interests of other constituencies, including current employees, retired employees, customers, and suppliers can be considered when making corporate decision. ${ }^{124}$ Connecticut even requires that the interests of other constituencies be taken into account in decisionmaking. ${ }^{125}$ Connecticut appears to be somewhat of an aberration though, because most states simply permit, rather than require these considerations.

Yet, the stakeholder constituency statutes are not without controversy. On their face, they appear to promote goals of corporate social responsibility, even if the goal of shareholder gain might not be served. As such, they have come under fire. Some commentators prefer a more direct anchor to shareholder interests. Nicholas Wolfson, ${ }^{126}$ Oliver Williamson, ${ }^{127}$ James W. Walker, Jr. ${ }^{128}$ and James D. Cox ${ }^{129}$ have

122 American Law Institute, Principles of CoRporate Governance: AnAlysis AND RECOMMENDATIONS, Section 2.01 (b) (2) (1994).

${ }^{123}$ American Law Institute, Principles of Corporate GovernanCE: ANALysis AND RECOMMENDATIONS, Section 2.01 (b) (3) (1994).

${ }^{124}$ N.Y. BUS. CORP. LAW $§ 717(\mathrm{~b})(1)(2002)$.

${ }^{125}$ CONN. GEN. STAT. §33-756 (2002).

${ }^{126}$ Nicholas Wolfson, A Critique of the American Institute Draft Proposals, 9 DEL. J. CORP. L. 629, 631 (1984).

127 Oliver E. Williamson, Corporate Governance, 93 YALE L.J. 1197, 1219 (1984).

${ }^{128}$ James W. Walker, Jr., Comments on the ALI Corporate Governance Project, 9 DEL. J. CORP. L. 580, 580 (1984). 
expressed this view, criticizing, in particular, the ALI approach. According to Wolfson, there is no empirical support for the ideas in the ALI model, and inclusion of these other objectives compromises efficiency and invites various tradeoffs. ${ }^{130}$ Perhaps even more troubling is M.J. Pritchett, III's argument that the ALI's optional approach might give management a free reign to promote their own self-interests under the guise of promoting social responsibility. ${ }^{131}$

The debate surrounding the role of the shareholder in the United States indicates that the U.S. approach to corporate governance is an approach based in shareholder primacy, but with a fair amount of built-in flexibility. That is, although shareholders still appear to be the most important constituent, the interests of other constituencies are significantly recognized.

In furtherance of the goal of providing value to shareholders, corporate law in the United States puts a great deal of emphasis on removing any hint of bias on the part of corporate directors. This has manifested itself in the increasing popularity of the “independent director." Independent directors hold mostly monitoring positions where they oversee actions of the CEO and other board members.

Irrespective of the arguments surrounding the weight American corporate boards can place on stakeholder interests who are not shareholders, the U.S. shareholder

${ }^{129}$ James D. Cox, The ALI, Institutionalization, and Disclosure: The Quest for the Outside Director's Spine, 61 GEO. WASH. L. Rev. 1212, 1212-13 (1993).

${ }^{130}$ Wolfson, supra note 126.

${ }^{131}$ M.J. Pritchett III, Comment, Corporate Ethics and Corporate Governance: A Critique of the ALI Statement on Corporate Governance Section 2.01(b), 71 CAL. L. Rev. 994, 1001, 1007 (1983). Others have criticized the ALI Project for opposite reasons. These detractors contend that the ALI approach simply articulates current business practice and is thus unnecessary. See, e.g., Donald E. Schwartz, Defining the Corporate Objective: Section 2.01 of the ALI's Principles, 52 GEO. WASH. L. REV. 511, 514 (1984). 
primacy model has created a corporate governance system which values transparency and disclosure. These values of transparency and disclosure are evident in both the federal and state securities laws and federal insider trading rules.

Federal and state securities laws are based on the premise that shareholders are entitled to full and fair disclosure regarding the nature of their investments. To effectuate full and fair disclosure, the federal securities regime, regulated by the Securities Act of $1933^{132}$ and the Securities Exchange Act of $1934,{ }^{133}$ requires corporations to disclose all significant aspects of their business before they can issue securities to the public. The Securities Act of 1933 mandates this disclosure by requiring any corporation wishing to sell its securities to the public to register its securities with the Securities and Exchange Commission. ${ }^{134}$ As part of the registration process, the corporation must prepare a prospectus, which discloses to potential investors the material aspects of the corporation's business. ${ }^{135}$ Information disclosed in the prospectus includes not only the price of the securities to be sold but also detailed financial information about the corporation. ${ }^{136}$ The corporation must also disclose information concerning its management and key shareholders. ${ }^{137}$ After a corporation's securities have been registered, the duty to disclose information continues on an annual basis ${ }^{138}$ or in the event of a major change within the corporate structure. ${ }^{139}$ If the

\footnotetext{
${ }^{132}$ The Securities Act of 1933, 15 U.S.C. $\S 77$ a et seq. (2002).

133 The Securities Exchange Act of 1934, 15 U.S.C. $\$ 78$ a et seq. (2002).

${ }^{134}$ See The Securities Act of 1933 § 5(a).

135 See id.; Regulation S-K, 17 C.F.R. 229 et. seq. (2002).

${ }^{136} 17$ C.F.R. 229.200, 229.300.

${ }^{137} \mathrm{Id}$.

${ }^{138}$ The Securities Exchange Act of $1934 \S 12(\mathrm{~g})(1)$ (requiring the annual filing of a Form $10-\mathrm{K}$ which discloses much the same information as required in the Securities Act registration).
} 
corporation decides not to sell its securities in a public offering, but instead in a private transaction, registration is not necessary, but in certain circumstances the corporation must still make similar disclosures to the purchasers of its securities. ${ }^{140}$ To supplement the federal rules, each state has its own disclosure rules concerning the sale of a corporation's securities within the boundaries of its state.

Strict penalties for noncompliance attempt to ensure American corporations take these disclosure and transparency rules seriously. A corporation that issues securities under a registration statement containing omissions or material misstatements exposes its officers, directors, underwriters and certain experts to civil liability. ${ }^{141}$ In addition, a corporation can be liable in the form of damages for any loss sustained by a purchaser of securities issued under a registration statement with omissions or material misstatements. In certain circumstances, a corporation may also be subject to criminal fines and penalties.

The ban on insider trading also highlights the importance American corporate governance regimes place on transparency and disclosure. The purpose of insider trading rules is to prevent any person from selling securities based on material, nonpublic, confidential information. Indeed, one of the policy rationales for regulating insider trading is that it is unfair to those who trade without access to the same information

${ }^{139} I d$. (requiring the filing of a Form 8-K disclosing specified events such as bankruptcy, merger, or a director's controversial resignation).

${ }^{140}$ See Rule 502(b)(2) (an issuer selling to any non-accredited investors in 505 or 506 exempt transactions must furnish its most recent annual report and any subsequent Exchange Act filings, along with a brief description of the particular offering otherwise the disclosure requirements vary with the size of the offering).

${ }^{141}$ See Rule 10b-5. 
available to insiders and others. ${ }^{142}$ The classic case of insider trading arises when a corporate insider buys or sells shares of the corporation using confidential information obtained through the insider's corporation position, and as a result, earns a profit. Federal common law has expanded the notion of insider trading, however, to include "outsider trading." Outsider trading occurs when a corporate insider learns that his firm (or a related firm) will do something that affects the value of another corporation's stock and trades using this information. ${ }^{143}$ Thus, insider trading emphasizes the American notion of disclosure by imposing on corporate insiders the duty to "abstain or disclose." "144 As part of this duty to "abstain or disclose," a corporate insider who possesses confidential information must either abstain from trading or disclose the information to the investing public. Failure to adhere to federal insider trading rules subjects the trader to liability under the Securities and Exchange Act Rule 10b-5. Indeed, the American emphasis on transparency and disclosure has been reaffirmed in light of the corporate accounting scandals of 2002 and the passage of the Sarbanes-Oxley legislation, whose implications for corporate governance has yet to be determined.

\section{The German Model}

The corporate governance model in Germany emanated from very different roots than the U.S. model. German corporate law, as originally enacted in 1935, did not even mention the shareholder as a constituency to be served by the corporation. Instead, it provided that " $[\mathrm{t}]$ he managing board is, on its own responsibility, to manage the

\footnotetext{
${ }^{142}$ This is should be compared with the absence of a duty of candor by corporate insiders to shareholders in anonymous trading markets as explained in Goodwin v. Agassiz, 186 N.E. 659 (Mass. 1933) (rejecting a duty of insiders to shareholder except in face-to-face dealings).

${ }^{143}$ See O’Hagan v. United States, 521 U.S. 642 (1997).
} 
corporation for the good of the enterprise and its retinue (Gefolgschaft), the common weal of the folk (Volk) and realm demand (Reich)."145 It was not until 1965 that shareholders were mentioned. ${ }^{146}$ In contrast to the United States, shareholders are only one of many constituencies served by the German corporate form.

Unlike the U.S, model, one constituency that appears to have some prominence in the German corporate governance model is the employee. Firms with more than 500 employees are required to utilize a two-tier board structure, with a supervisory board providing oversight and general corporate strategy and a management board providing more of a day-to-day management oversight function. ${ }^{147}$ If the firm has more than 2,000 employees, $50 \%$ of the supervisory board must consist of employee representatives. ${ }^{148}$ The remaining $50 \%$ consists of shareholder representatives. ${ }^{149}$ The management board consists almost entirely of the senior management of the company. ${ }^{150}$ Board members tend to possess technical skills related to the product, in addition to considerable firm- and industry-specific knowledge. This is because careers are often built up from the ground level and are focused on building asset-specific skills through extensive apprenticeship systems. The result of the two-tiered board structure is explicit representation of stakeholder interest other than interests of shareholders --

${ }^{144}$ See SEC v. Texas Gulf Sulphur, 401 F.2d 833 (1968).

${ }^{145}$ Bradley, et al., supra note 108, at 52; Detlev F. Vagts, Reforming the "Modern" Corporation: Perspectives from the German, 80 HARV. L. REV. 23, 40 (1966).

${ }^{146}$ Vagts, supra note 145, at 40-41.

${ }^{147}$ Bradley et al., supra note 108 , at 52.

${ }^{148} \mathrm{Id}$. at 53 (indicating that the other $50 \%$ of the supervisory board consists of shareholder representatives).

${ }^{149} \mathrm{Id}$.

${ }^{150}$ Stephen Prowse, Corporate Governance in an International Perspective: A Survey of Corporate Control Mechanisms Among Large Firms in the United States, the United 
no major decisions are made without the input employee representatives. ${ }^{151}$ This is in stark contrast to the structure of corporate boards in the United States where the board structure is single-tier and labor has no right of representation. In fact, board members in the U.S. are required to act in the best interest of the corporation and its shareholder and may not specifically represent any particular constituency.

Banks play a larger role in German corporate governance than they do in the United States. Approximately fourteen percent of corporate shares are owned by banks. $^{152}$ More importantly, a substantial portion of equity is in the form of bearer, rather than registered stock, ${ }^{153}$ and these shares are left on deposit with the Hausbank of the corporation, which handles dividend payments and record keeping. ${ }^{154}$ German law allows banks to vote such equity on proxy, unless depositors explicitly instruct banks to do otherwise. ${ }^{155}$ It appears inertia "work[s] in favor of banks having proxy votes."156 The power banks hold in German corporations is compounded by the fact that many company charters include a provision disallowing non-bank shareholders to exercise more than five to ten percent of the total votes, regardless of the proportion of shares they own. ${ }^{157}$

Kingdom, Japan, and Germany, BANK FOR INTERNATIONAL SETTLEMENTS ECONOMIC PAPERS No. 41, 43 (July 1994).

${ }^{151} I d$.

152 Organization for ECON. COOPERATION AND DEV., ECONOMIC SURVEYs: Germany 87 (1995) [hereinafter OECD GERMANY].

${ }^{153}$ Mitsuhiro Fukao, Financial InTEgration, Corporate Goverance AND the PERFormanCE of Multinational Corporations 27 (1999).

${ }^{154}$ See OECD GERMANY, supra note 152, at 89.

${ }^{155}$ FUKAO, supra note 153, at 27.

${ }^{156}$ Bradley et al, supra note 108 , at 54 .

${ }^{157}$ FUKAO, supra note 153 , at 27. 
The role of the bank in German corporate governance is also strengthened by financing patterns. German companies, taken as a whole, are more leveraged than their American counterparts. ${ }^{158}$ Moreover, instead of relying on public debt financing, German companies finance their debt through bank or intermediated loans. ${ }^{159}$ Bank financing of long term debt has averaged around $50 \%$, and this percentage has remained fairly stable throughout the past two decades. ${ }^{160}$

Creditor interests are also protected through corporate governance regimes. ${ }^{161}$ Dividend payout rules are designed to protect creditor interests. ${ }^{162}$ German law stipulates that dividends may not be paid out from paid-in capital, even if such paid-in capital includes a premium over the face value of equity. ${ }^{163}$ This provision makes it difficult for German corporations to undertake share repurchases, ${ }^{164}$ and consequently, also makes it difficult for German shareholders to cash out of the corporation. ${ }^{165}$

The incorporation of other stakeholder interests in corporate decision-making affects governance issues like management compensation. Unlike in the United States, the compensation of German board members must be approved by the shareholders, and this approval affects the amount and structure of compensation. In 1997, CEOs of listed German companies earned about half of what their American counterparts

\footnotetext{
${ }^{158}$ Bradley et al., supra note 108 , at 54.

${ }^{159}$ Prowse, supra note 150 , at 93.

${ }^{160}$ See OECD GERMANY, supra note 152, at 93.

${ }^{161}$ German bankruptcy law is also skewed toward protecting creditor interest. See FUKAO, supra note 153, at 123.

${ }^{162}$ Bradley et al, supra note 108, at 55.

${ }^{163}$ FUKAO, supra note 153, at 120.

${ }^{164} \mathrm{Id}$.

${ }^{165}$ See, e.g., Bradley et al, supra note 108, at 54.
} 
earned, ${ }^{166}$ and their compensation usually takes the form of fixed salaries and bonuses. ${ }^{167}$ Providing stocks or stock options as part of top-management's compensation packages is still fairly rare. ${ }^{168}$

Although corporate governance in Germany explicitly takes into account stakeholder interests other than shareholders, compared to U.S. firms, the quality of disclosure in German firms is poor. ${ }^{169}$ The legal and regulatory framework for disclosure is considered relatively lax, compared to that in the United States. ${ }^{170}$ An OECD survey of disclosure quality states that, as of 1989, none of the German firms in their sample had complied fully with OECD disclosure guidelines. ${ }^{171}$ Similarly, until recently, Germany had no insider-trading laws; if insider trading was discovered, the penalty was simply to turn over the profits. ${ }^{172}$

\section{Japanese Model}

The traditional corporate governance model in Japan has, like the German model, emphasized protection of employee interests, as well as creditor interests. There has been little incentive to be concerned with shareholder value, per se. This may be due in large part to Japan's corporate ownership structure. Historically, firms in Japan have been networked in the form of keiretsus, groups of firms that own reciprocal, minority interests in each other. ${ }^{173}$ Although the firms in a keiretsus are usually independent,

\footnotetext{
${ }^{166}$ KeVIn J. Murphy, 3 HandBOOK OF LABOr ECONOMics tbl. 4 (1999).

${ }^{167}$ Bradley et al., supra note 108 , at 53.

${ }^{168} \mathrm{Id}$.

${ }^{169} I d$. at 55 .

${ }^{170} \mathrm{Id}$.

${ }^{171}$ See Prowse, supra note 150 , at 29.

172 Bradley et al., supra note 108 , at 56.

${ }^{173}$ FUKAO, supra note 153 , at 2 . Fukao translates keiretsus as "a series of things organized to perform a function." For more details on the Japanese keiretsu, see
} 
they to have relational and implicit contracts with each other on matters such as ownership, governance, and commercial contracts. ${ }^{174}$

Like Germany, banks also play a significant role in Japanese corporate governance structures. For example, a large main bank that conducts business with all of the member firms and holds minority equity positions in each will be a member of a horizontal keiretsu. Although a single bank is not allowed to hold more than $5 \%$ of a single firm's stock, a group of four or five banks typically may control between $20-25 \%$ of the company's stock. ${ }^{175}$ More importantly, the corporation's largest bank shareholder is often the largest creditor. Thus, the interest of the shareholder is in effect the same as the interest of the creditor. Banks, as creditors and shareholders, are more concerned about credit risk than return on the stock investment, and thus are more interested in long-term growth than short-term profits. Thus, the interest of the "shareholder" is in fact aligned with the interest of the "creditor." This proportion has remained fairly stable over the past fifteen years, and these closely held shares rarely, if ever, make it into the financial marketplace. ${ }^{176}$ Japanese corporations are also typically more leveraged than corporations in the United States. The largest bank shareholder also is usually the largest debtholder in the company. ${ }^{177}$

generally W. CARL Kester, JAPANese TAKeOVERs: The Global CONTEST For CORPORATE CONTROL 54-55 (1991); Erik Berglof \& Enrico Perotti, The Governance Structure of the Japanese Financial Keiretsu, 36 J. FIN. ECON. 259 (1994); David Flath, Shareholdings in the Keiretsu, Japan's Financial Groups, ECON. PERSP., Jan.-Feb. 1991, at 20.

${ }^{174}$ See Bradley et al., supra note 108, at 57.

${ }^{175}$ FUKAO, supra note 153 , at 15.

${ }^{176} \mathrm{Id}$.

${ }^{177} \mathrm{Id}$. 
Quite apart from the lending and the direct intervention roles they play, banks also may facilitate the governance process. They are likely to have a great deal of access to inside information and hence can perform a monitoring role very effectively. ${ }^{178}$ Given the governance role of the banks, resolution of financial distress is a much more informal process as compared to the United States. This is also true in Germany.

In addition to protection of creditor interests, Japanese corporate governance is also concerned with employee interests. Japan has also been historically known for the practice of "lifetime employment."179 Employees have remained at their firms due to the grant of responsibility and benefits this has provided. ${ }^{180}$ The early retirement age in Japan, at 55, may also contribute to this practice of "lifetime employment.", 181

The structure of boards in Japan is similar to that in the Anglo-American system with single-tier boards. ${ }^{182}$ However, in terms of membership, the Japanese board is similar to the German board. A substantial majority of board members consist of current or former senior and middle management of the company. ${ }^{183}$ Fukao notes that nearly $78 \%$ of Japanese directors are promoted from among employees. ${ }^{184}$ Thus, unlike in the United States, outside directorships are rare. The one exception to outside directorships is the main banks. Their representatives usually sit on the boards of the

${ }^{178} \mathrm{Id}$.

${ }^{179}$ Masahiko Aoki, Toward an Economic Model of The Japanese Firm, 28 J. ECON. LiterATURE, 1, 11-12 (1990); Ronald J. Gilson \& Mark J. Roe, Essay, Lifetime Employment: Labor and Peace and the Evolution of Japanese Corporate Governance, 99 COLUM. L. REV. 508, 529 (1999).

${ }^{180}$ Wai Shun Wilson Leung, The Inadequacy of Shareholder Primacy: A Proposed Corporate Regime that Recognizes Non-Shareholder Interests, 30 COLUM. J.L. \& SoC. PROBS. 587, 630 n. 223 (1997).

${ }^{181}$ Gilson \& Roe, supra note 179, at 530.

182 Prowse, supra note 150 , at 42.

${ }^{183}$ FUKAO, supra note 153, at 14. 
keiretsu firms with whom they do business. ${ }^{185}$ However, unlike in Germany where employees and sometimes suppliers tend to have explicit board representation, the interest of stakeholders other than management or banks are not directly represented on Japanese boards. $^{186}$

Unlike in Germany, management compensation is not a matter for shareholder approval. Compensation, including that of top management, relies on salaries and bonuses. ${ }^{187}$ Stocks or stock options are rarely used as a basis for remuneration. Total compensation of top managers, including bonuses, is about six to eight times the compensation of the most highly paid blue-collar worker and about seventeen times that of the average worker. ${ }^{188}$ A managerial labor market along U.S. lines, especially for mid-career workers, is thin. ${ }^{189}$

Share ownership in Japan is concentrated and stable. Individual share ownership in Japan, like in Germany, has steadily declined from about fifty percent in the 1950s to about twenty percent at present. Thus, in a typical Japanese firm, approximately twothirds of the equity is owned by banks, insurance companies, and other corporations. ${ }^{190}$

Internal management styles and control systems in Japanese firms rely on building long-term, consensus-based relationships and are characterized by a great deal of informal interactions, personal relations, and information-sharing among relatively

${ }^{84} \mathrm{Id}$.

${ }^{185} \mathrm{Id}$. at 25.

${ }^{186}$ Bradley et al, supra note 108 , at 58 .

${ }^{187}$ OECD GERMANY, supra note 152, at 107 fig. 10.

188 See FUKAO, supra note 153, at 17.

${ }^{189} \mathrm{Id}$. at 57.

${ }^{190}$ Bradley et al, supra note 108 , at 60 . 
culturally homogeneous individuals. ${ }^{191}$ There is an apparent reliance on trust, reputation-building, and face-saving considerations as the basis for contracting, ${ }^{192}$ in part because the corporation is seen by its employees as much as a social entity as an economic entity. ${ }^{193}$ Companies thus rely on face-to-face contacts to resolve issues. ${ }^{194}$ Japanese firms in the larger, organized sector of the economy emphasize lifetime employment and building human capital by maximizing asset-specific and relationspecific skills. Lateral inter-functional transfers of managers and horizontal information flows among functions and departments, both within the firm and across firms within the network, are common. ${ }^{195}$ Upward mobility within Japanese organizations is carried out through a process of moving up through a cross-functional spiral rather than through a series of promotions within a particular functional area. ${ }^{196}$

Disclosure quality, although considered superior to that of German companies, is poor relative to that of U.S. firms. Although there are rules against insider trading and monopolistic practices, the application of these laws is, at best, uneven and inconsistent. $^{197}$

\section{B. Corporate Governance Regimes and Sustainable Peace}

\section{A Comparative Assessment}

It is important to remember that the corporate governance models of the United States, Germany, and Japan are rooted in democratic political entities. Or to frame this in

\footnotetext{
${ }^{91} I d$. at 60.

${ }^{192} I d$.

${ }^{193} \mathrm{Id}$.

${ }^{194} \mathrm{Id}$.

${ }^{195}$ Id. at 61.

${ }^{196} \mathrm{Id}$.

${ }^{197}$ Id.
} 
Bobbitt's terms, the Entrepreneurial, Managerial, and Mercantile Models are embedded in parliamentary democracies. ${ }^{198}$ The question becomes to what extent to the descriptions of the varying regimes raise the concerns expressed by Barber that corporations themselves tend to undermine the very democratic virtues that lead to sustainable peace. ${ }^{199}$ To analyze these issues, we compare these alternatives on the basis of: (1) the corporation's sense of citizenship; and (2) the extent to which corporations equip citizens with voice in the affairs that affect them. In doing so, a model emerges that suggests that corporations of each parliamentary democracy might wish to consider: (1) the creation of authentic communities that encourage peace rather than a solipsistic notion of community; and (2) the opportunities and dangers in extended beneficial attributes of voice and citizenship to groups not typically accorded those attributes as well as how these extensions can best be accomplished. After sketching these crosscutting notions, we propose four contributions corporations can make to sustainable peace, not in the sense of a universal model for corporate governance, but as a set of criteria that corporate regimes might generally aim toward, within the context of their own cultural histories and realities.

\section{a. Citizenship and Voice}

\section{i. Citizenship}

For several years, corporate governance scholarship has focused on a debate between contractarian and communitarian approaches. ${ }^{200}$ In an important sense, this debate is related to Barber's concern as to whether corporations create a McWorld that

\footnotetext{
198 BOBBITT, supra note 14.

${ }^{199}$ BARBER, supra note 36; see also supra notes 82-88 and accompanying text.
} 
undermines democratic values by undermining a sense of citizenship. ${ }^{201}$ In a contractarian paradigm, which underscores the U.S. version of the Entrepreneurial model, notions of citizenship are likely to revolve around legally enforceable duties, such as obeying laws generally and, more particularly, those laws that protect investors through fiduciary duty, securities, and other regulation. ${ }^{202}$ Thus, according to Bobbitt and Barber, the notion of citizenship in this model is thinner than in other models. Yet, for example, the U.S. variant on this model has been flexible enough to accommodate various notions of citizenship, as evidenced by adoption of statutes in a majority of states that explicitly permit management to consider the interests of constituencies other than shareholders when making decisions.

The notions of citizenship may be more pronounced in the German (Managerial) and Japanese (Mercantile) model, however. ${ }^{203}$ In both models, there is an expectation of corporations serving a societal good. In Germany, this is explicit in a stakeholder model that directs the company to be concerned with society generally as well as employees and creditors. $^{204}$ In Japan, this is tied to cultural notions of solidarity and employee enmeshment with work. $^{205}$ In both cases, there is a clear understanding that corporations are part of a greater social fabric and duties attending to the maintenance of that fabric. It would seem that the introduction of a commitment to a public good, such as sustainable peace (provided that sufficient empirical support is established to make plausible the case

200 See, Bradley, et. al. supra note 108 (providing a comprehensive analysis of the various arguments for competing styles of contemporary corporate governance).

${ }^{201}$ BARBER, supra note 36; see also supra notes 89-95 and accompanying text.

${ }^{202}$ See infra notes 249-50 and accompanying text (with respect to free market arguments from Hayek and Friedman, which focus on the importance of laws).

${ }^{203}$ See supra notes 51-67 and accompanying text.

${ }^{204}$ See supra note 61-67 and accompanying text. 
that corporations can, in fact, have an impact on social stability), could be incorporated into these models.

\section{ii. Voice}

As important as the societal purposes of corporations is the extent to which the key democratic virtue of voice is fostered varies according to each model. Although citizenship notions seem to be more akin to Germany and Japanese models, the U.S. model may have greater sensitivity to voice. As we have seen, the U.S. model emphasizes transparency and disclosure. ${ }^{206}$ Both equip a recipient with the capability to exercise voice. This voice is particularly important insofar as investors are concerned, but disclosure and transparency have other significant beneficial effects with respect to sustainable peace as demonstrated below. ${ }^{207}$ They give other stakeholders information by which they can more powerfully exercise their own voice, even if it is simply in criticism of the corporation itself. The 2002 corporate scandals demonstrate that the Entrepreneurial Model is not perfect in its accurate disclosure of information. The scandals demonstrate the need for even better transparency and disclosure and they also demonstrate another powerful constituent voice: that of management itself.

Management's voice is also heard strongly in the Mercantile and Managerial Models. In the Mercantile Model, the strong voice of management, together with that of other corporate leadership represented through cross-ownership mediated through creditors dominates corporate affairs. ${ }^{208}$ Similarly, the Managerial Model also

\footnotetext{
205 See supra note 52-61 and accompanying text.

${ }^{206}$ See Bradley, et. al., supra note 108.

${ }^{207}$ See infra notes 238-47 and accompanying text.

${ }^{208}$ See supra notes 173-208 and accompanying text for a discussion of the Japanese version of the Mercantile Model.
} 
emphasizes the voice of creditors and senior management. ${ }^{209}$ In addition, however, the Managerial Model features the institutionally empowered voice of employees through board representation and society in general. ${ }^{210}$ Yet, given the diminished degree of transparency and disclosure in both models, the capability of dissent is minimized. Only a few individuals have access to the information necessary to exercise voice meaningfully. Thus, although the Managerial and Mercantile Models are both more communitarian and thus theoretically more conducive to a goal of peaceful stability, they lack a central attribute essential to stability.

\section{b. Mediating Institutions and Lessons to Counteract Cynicism}

\section{i. Mediating Institutions}

In previous work, we argued for a blended model of corporate governance. ${ }^{211}$ This model featured enhanced notions of transparency and disclosure for German and Japanese regimes and a greater sense of community for the U.S. system. ${ }^{212}$ Yet a common problem for each of the regimes, regardless of whether they were more communitarian or more contractarian, was the potential diminishment of the individual in a large society. Indeed, we began our article with a comment by Vaclev Havel, where he notes that both capitalist corporations and socialist plants shared the common problem of being so large so as to dwarf the individual working for it. ${ }^{213}$ This can be true of a large

\footnotetext{
${ }^{209}$ See supra notes 152-68 and accompanying text for a discussion of the German version of the Managerial Model.

${ }^{210}$ See supra notes 147-51 and accompanying text for a discussion of the German approach.

${ }^{211}$ Fort \& Schipani, supra note 113.

${ }^{212} \mathrm{Id}$.

${ }^{213} I d$.
} 
U.S. company, but it can also be true of an organization that is devoted to the entire nation-state of Germany or Japan. ${ }^{214}$

In opposition to the model of a corporation as a megastructure, we proposed the model of business as a mediating institution, where are small enough so that individuals interact with others in their organization on an interpersonal basis, experience the consequences of their actions, and develop their moral identity. ${ }^{215}$ This is not to suggest that corporations be limited in size, but it is to suggest that corporations consciously attempt to structure themselves to have communities within their overall corporate structure. $^{216}$ Such a model could preserve and even enhance an authentic community identity of the corporation while at the same time also require the kind of transparency and disclosure that supports voice. ${ }^{217}$ Moreover, as discussed below, anthropologists have found that the traits of mediating institutions - relatively small, face-to-face interactions, reduced hierarchy and consensual decision-making - are all attribute of peaceful societies. $^{218}$ Thus, a model of communities within corporations is a potential model for peaceful societies as well as scheme that addresses a problem of corporate megastructure size that is common to companies in each regime.

\section{ii. Lessons to Counteract Cynicism}

${ }^{214}$ See Fort \& Schipani, supra note 113 (arguing that large communities can inhibit the capacity of an individual to feel that $\mathrm{s} /$ he makes an authentic contribution to the welfare of that community).

${ }^{215} \mathrm{Id}$.

${ }^{216}$ See Fort \& Schipani, supra note 113 (arguing for the need of relatively small groupings within the corporation to address the human need for relatively small groups). ${ }^{217}$ See generally, Fort \& Schipani, supra note 113 (arguing that such a corporate structure might serve as the best of all possible worlds).

218 See infra note 258 and accompanying text (noting the work of anthropologist David Fabbro). 
In a later article in this volume, Professor Dana Muir discusses the history of employee benefit programs as related to issues surrounding peace. ${ }^{219}$ Muir notes that employee benefit programs have been championed as a way to mitigate some of the harshness of capitalism so that employees believed that they were, in fact, participants in the system as opposed to be exploited by the system. ${ }^{220}$ Muir traces this hope in the United States and in other countries and suggests that such programs offer some degree of participation that fosters harmony over competition. ${ }^{221}$ Yet, she also warns, that superficial programs, those that promise employee involvement, participation, and voice, but do not deliver, can sew the seeds of cynicism. ${ }^{222}$ This potential problem exists, for instance, in employee programs where putative employee stock owners do not have the right to vote the stock they own unlike other shareholders. ${ }^{223}$

Professor Muir's warnings are apt for any extension of "benefits" to a group not traditionally having them. Whether Japanese, German, or American, the extension of a right to those who otherwise have not had it, may engender as much suspicion as gratitude. Thus, if the promise of voice, participation, ownership, transparency, disclosure or other attributes that appear to be beneficial to harmonious relationships is not fulfilled, there is a risk of increasing cynicism and distrust. At the same time, Muir's analysis shows that there are models for such extensions that could prove to be beneficial to connecting business and peace.

\section{c. Concluding Thoughts: Comparative Assessment}

\footnotetext{
${ }^{219}$ Muir, supra note 13.

${ }^{220} \mathrm{Id}$.

${ }^{221} I d$.

${ }^{222} \mathrm{Id}$.

${ }^{223} I d$.
} 
From the foregoing analysis, it does not appear that there is anything inherently problematic about connecting corporate governance and sustainable peace. In each country, there is openness to values in addition to profitability for shareholders. Although maximizing shareholder value is clearly an important, overriding goal for a corporation and for the nation states establishing the legal governance rules for the society, Anglo-American law allows for consideration of non-shareholder constituents, Japanese law provides room for concern for the social aspect of work, and German law is concerned for employee and social welfare in business management. Although questing for sustainable peace may sound idealistic, it is also a goal that benefits corporations themselves, if they are able to contribute to societies that tend to be more stable in the long run and more peaceful. Thus, there is a plausible long-term reason for why businesses have an interest in sustainable peace and an openness within corporate governance regimes to pursue it as a goal. To be sure, it would be even more conducive to making this goal a widely endorsed corporate goal, if extant governance regimes were to specify its legitimacy. Yet, even without legal change, corporations can adapt current practices in order to integrate the goal of sustainable peace into a transnational corporate goal.

This quest will require some adaptations of corporate governance, but in a world where access to powerful technologies of violence is relatively easy, it becomes incumbent on corporations (as well as other citizens) to consider what contributions they might be able to make to a world that, for reasons of survival itself, evolves. With this in mind, we propose four ways in which corporations might be able to contribute to sustainable peace. This proposal is not made in definitive terms. It is not presented a 
proven mechanism for achieving sustainable peace. Instead, our ambition is to sketch a plausible way for corporations to contribute to sustainable peace corresponding with existing evidence.

\section{A Proposed Model of Corporate Action}

As we have suggested in this article and developed more fully in previous work, there is a plausible, conceptual relationship among the role of business, business ethics and sustainable peace. ${ }^{224}$ The gist of this argument is that through economic progress and mitigation of rivalries in the workplace, multinational corporations can contribute to sustainable peace. Business can do this by:

(1) fostering economic development, particularly for the marginalized;

(2) adopting external evaluation principles, such as transparency and supporting a legal system that enforces those principles, i.e,. a "rule of law;"

(3) nourishing a sense of community both within the company and in the areas in which the company is located; and

(4) mediating potentially conflicting parties and redirecting those parties toward a common goal, even if that goal is only that of profitability.

We wish to sketch this model conceptually and illustrate the themes by the actions of specific companies. In doing so, we are not suggesting that these attributes be uncritically accepted as a model for peaceful corporate governance. There is, however, evidence to show connections between the characteristics and sustainable peace and suggest that corporate governance regimes, attentive to the comparative concerns already raised, can integrate these characteristics in culturally appropriate ways.

\section{a. Fostering Economic Development}

The first thing companies can do to help work toward the goal of peace is what they do best: foster economic development. A recent United Nations report showed a 
highly positive correlation between underdevelopment and violence. Intuitively, this correlation makes sense: in an environment of extremely scarce resources, competition for the necessities of life could lead to conflict that could turn violent. Although critics of globalization often downplay the economic advantages corporations bring with them to country, there are a number of ways in which corporations contribute to more stable societies.

The first contribution corporations make toward stability is in providing jobs to residents of the country. For instance, Frigorifico Canelones, a division of Land O'Frost and recognized by the U.S. Secretary of State as a winner of the Award for Corporate Excellence, ${ }^{225}$ turned a bankrupt meat processing plant into a profitable

${ }^{224}$ See generally, Fort \& Schipani, supra note 12.

${ }^{225}$ The criteria for the Secretary of State's Award for Corporate Excellence are:

- Maintaining good corporate citizenship by engaging in ethical business practices, maintaining the integrity of the company, and dealing with consumers in accordance with fair business practices.

- Displaying exemplary employment practices and a fair opportunity for trade unions to represent employees as well as avoiding discrimination based on race, gender or ethnicity.

- Creating a healthy workplace environment for all workers. This includes working for the effective abolition of child labor and forced labor practices as well as maintaining a working environment equal to, if not exceeding, comparable local industry standards of health and safety.

- Conducting business with an astute consciousness of local, national, and global environmental concerns. This includes the collection and ongoing monitoring of useful information regarding the environmental, health, and social impacts of operations. Also, working with local, national, and international officials to adequately communicate to the public regarding potential environmental and health issues without compromising the business's integrity and ability to operate successfully.

- Contributing to the overall growth and development both economically and socially of the local society. This includes work-specific skills training, general academic improvement, and opportunities for personal self-improvement, as well as other programs, services and philanthropic endeavors for the local public, all aimed at providing a base for growing and sustaining an increased quality of life. 
Uruguayan operation. ${ }^{226}$ The resulting 800 jobs, in a town with no other major employer, provided economic development to an impoverished area. ${ }^{227}$ The same kind of experiences holds true in Malaysia, where Motorola, also an Award winner, invested $\$ 1.1$ billion and employed more than 8,000 people, as well as in Ethiopia, through the work of F.C. Schaffer \& Associates, a small Louisiana sugar company employing 7,000 people. ${ }^{228}$

The second corporate contribution results from the benefits they can provide to the local population. For example, Frigorifico Canelones supports training and educational programs for homeless and abused youth as well as recreational programs for children. ${ }^{229}$ Ford Motor Co., also a winner of the Award for Corporate Excellence, sponsors AIDS-related programs in Africa, working with local health care authorities. ${ }^{230}$ Xerox, which won an Award in 1999, not only contributes to programs for children, but also addresses another stakeholder group - employees - by providing counseling programs designed to help lift people out of poverty in Brazil. ${ }^{231}$ In addition, it offers space in its facilities for local cultural activities. ${ }^{232}$

- Endeavoring to ensure that business activities are compatible with the science and technology policies of the countries and, as appropriate, contribute to the development of local innovative capacity.

- Developing and maintaining a healthy respect for the local, national, and international authority. This includes rejecting the practices of bribery, extortion, illegal tax exemption, and favoritism in favor of creating a fair and open marketplace beneficial to all. http://www.state.gov/search.htm.

226 Frigorifico Canelones at http://www.state.gov/search.htm.

${ }^{227} \mathrm{Id}$.

${ }^{228}$ F.C. Schaffer \& Associates at http://www.state.gov/search.htm.

${ }^{229}$ Frigorifico Canelones at http://www.state.gov/search.htm.

${ }^{230}$ Ford, at at http://www.state.gov/search.htm.

${ }^{231}$ Xerox, at at http://www.state.gov/search.htm.

${ }^{232} \mathrm{Id}$. 
The third contribution relates to resource transfer. This transfer could be in technological development or development of human managerial capabilities, or both. Motorola's work in Malaysia exemplifies both features of this dimension. By building a high-tech manufacturing plant, it provides technological know-how to the Malay people, ${ }^{233}$ which itself provides a foundation for additional economic development. Moreover, the managers of Motorola's facilities are not ex-patriots, but citizens of Malaysia, ${ }^{234}$ thereby transferring managerial skills are transferred to the country as well. F.C. Schaffer \& Associates also exhibits these characteristics with a bit of a novel twist. After devastating floods racked Ethiopia, the company shared its expertise in running sugar refineries with competitors. ${ }^{235}$ It continues to provide consulting services for the design of co-generation, environmentally safe power plants. ${ }^{236}$

A fourth contribution is the simple task of paying taxes. The benefit to society provided by tax revenues, however, is dependent on the quality of the government collecting the taxes and the use made of them. Assuming just governmental regimes, tax revenues may be quite beneficial in helping to provide a much needed infrastructure.

If a key factor in violence is the desperation produced by marginalization, then the work of companies such as these avoids exploitation. These companies have built local capacities while also being profitable. Ethics scholar, Michael Santoro, has argued that there is a difference between companies that exploit low-wage economies by creating sweatshops as a cost-minimization strategy and others that adopt a market-building

\footnotetext{
${ }^{233}$ Motorola, at at http://www.state.gov/search.htm. ${ }^{234} \mathrm{Id}$.

${ }^{235}$ F.C. Schaffer, at http://www.state.gov/search.htm.
} 
strategy. ${ }^{237}$ The first is more likely to sow the seeds of resentment. The second is a contribution to the welfare of the countries in which companies do their work.

\section{b. Adopting External Evaluation Principles}

With modern communications technology, it is difficult for any company to be immune from the potential glare of publicity and investigative reporting. Yet some companies welcome transparency. To be transparent is to be willing to have your actions evaluated by others. Although not all transparency is universally good - there are, after all balances that need to be struck between transparency and privacy accountability to external standards may contribute to a social environment where violence is less likely to occur. Two aspects of transparency are particularly worth noting: transparency with respect to corruption and support of a rule of law.

In previous research, we conducted an analysis of whether there is a connection between corruption and violence. ${ }^{238}$ We compared the ranking of countries by Transparency International in its Corruption Perception Index with the Heidelberg Institute for International Conflict Research's index related to conflict around the world. $^{239}$ The Corruption Perception Index is based on interviews with approximately 770 managers and other business people about the extent to which corruption is endemic in a country in which they work. ${ }^{240}$ The Heidelberg Institute keeps track of conflicts that occur within a country and evaluates them according to whether they are

\footnotetext{
${ }^{236} \mathrm{Id}$.

${ }^{237} \mathrm{Id}$.

${ }^{238}$ Fort \& Schipani, supra note 12, at 398.

${ }^{239} I d$. at 398.

${ }^{240}$ Transparency International, The 2000 Corruption Perceptions Index, at http://www.transparency.de/documents/cpi/2000/cpi2000.html.
} 
handled in a nonviolent or violent way. ${ }^{241}$ The assessment tracks twenty-eight different attributes, and also provides a four-part characterization of whether disputes are handled mostly violently, somewhat violently, somewhat nonviolently, and mostly nonviolently. $^{242}$

The results were striking. Countries in the top quartile of the TI index, that is, those countries that were the least corrupt, resolved disputes by violence $14 \%$ of the time. $^{243}$ Those in the second quartile resolved disputes by violence $26 \%$ of the time. ${ }^{244}$ The third quartile resolved disputes by violence $44 \%$ of the time and those in the bottom TI quartile, that is the most corrupt, resolved disputes by violence $60 \%$ of the time. $^{245}$ These findings are correlative, not causative. Yet, it is possible that poverty may contribute to corruption which leads to violence. If so, then underdevelopment may be more of a root cause to violence that corruption per se. Nevertheless, it is hard to see how more corruption will help a social situation.

John Noonan, an expert in the study of bribery, once noted that bribery is typically hidden unless the leaders are so brazen and secure in their power that they can flaunt their corruption. ${ }^{246}$ That which is hidden, by tautology, is not subject to external evaluation. In fact, the goal of the efforts of TI is to publicize incidents of corruption. Keeping corruption hidden denies the opportunity to raise meaningful objections to the practice. As ethicists Thomas Donaldson and Thomas Dunfee have argued, keeping

${ }^{241}$ Heidelberg Institute for International Conflict Research, at http://www.conflict.com/hiik/manual_en.html.

${ }^{242}$ Id.

${ }^{243}$ Fort \& Schipani, supra note 12, at 398.

${ }^{244} I d$.

${ }^{245} I d$.

246 See John T. NoOnAn, BriBEs (1984). 
bribery hidden skews the efficient distribution of resources because decisions are not made on the basis of a merit that can be publicly evaluated and justified, but on the basis of a kind of power that is immune from evaluation. ${ }^{247}$ Corruption stifles the voice of people evaluating the action.

No one company is going to solve a country's corruption problems. Yet, companies can try to limit the corruption endemic to a country and also work to try to change the enforcement of laws so that anti-bribery laws are effective. Indeed, this is the recommendation of the OECD in order to promote efficient markets. ${ }^{248}$ Moreover, if there is also a correlation between corruption and violence, then the cause of peace could be beneficially supported by corporate efforts to limit or eliminate corruption.

This commitment to support laws that reduce or eliminate bribery lead to the second kind of evaluative commitment: support of the rule of law itself. One of the clear lessons from the emerging economies of central and Eastern Europe after 1989 is that those countries that quickly established a commitment to a rule of law, particularly in terms of contract and property protection, flourished more than others. Even the free market is not completely free - it requires a legal and moral infrastructure to work. This has been acknowledged by devout free marketers such as F.A. ${ }^{249}$ and Milton Friedman. ${ }^{250}$ Perhaps even more interestingly, economist Jane Jacobs has argued that

\footnotetext{
${ }^{247}$ DONALDSOn \& Dunfee, Ties That Bind 226-30 (2000).

${ }^{248}$ See, Miguel Scholoss, Luncheon Address at the Symposium on Fighting International Corruption \& Bribery in the $21^{\text {st }}$ Century 33 CORNELL J. INT'L L. 469, 478 (2000); see also DONALDSON \& DUNFEE, supra note 247.

${ }^{249}$ See F.A. HAYeK, The FATAL ConCEIT (1988) (arguing that the free market depends on legal protection of contracts and property rights).

${ }^{250}$ Milton Friedman, The Social Responsibility of Business is to Increase Its Profits, N.Y. TIMES MAG. (1970) (arguing that the free market is dependent upon a functioning legal system that restrains some kinds of behavior).
} 
those countries with strong commercial values, including values of promise-keeping in contracts, respect for property, and nonviolent, negotiated resolution of disputes, tend to be more peaceful. $^{251}$

There are at least three ways in which companies can support a rule of law. First, they can comply with legal requirements. ${ }^{252}$ Unfortunately, not all laws are just. Nevertheless, compliance with most legal requirements typically yields good results. Second, they can educate people about laws are and how they can be useful. Johnson \& Johnson currently operates a program in rural China in conjunction with the Chinese government and UNICEF that teaches healthcare workers about regulations pertaining to childbirth. This is done with the hope of increasing the knowledge of midwives and other healthcare providers to improve the quality of medical services. Thus, by teaching people about law, living conditions can by improved.

A third way is more controversial. Hernando de Soto has made a provocative argument claiming that nearly $\$ 1.3$ trillion lay in the hands of the very poor around the world. ${ }^{253}$ The problem is that the poor are unable to access those resources because the most valuable assets are their homes and the legal title requirements in emerging countries often do not allow the marginalized to acquire clear title to their homes. Without title, the poor cannot exercise the most basic of entrepreneurial strategies of taking out a home loan to start a business. As a result, there is enormous potential that could be unleashed if certain kinds of property systems - akin to the Homestead Act in

${ }^{251}$ See generally JANE JaCOBS, Systems of SuRViVAL: A Dialogue On the Moral Foundations of COMMERCE AND POLITICs (1992)

${ }^{252}$ See sources cited supra note 225 and accompanying text (specifying rule of law as a criteria for the Award of Excellence). 
the United States in the early part of its history ${ }^{254}$ - are developed. Clearly, this is a legal reform dependent upon governmental action, but corporations have influence, often significant influence in law reform. De Soto's point is that such reforms would improve the plight of the marginalized, which itself would be contribution to stability, and also provide more economic opportunity as the creative potential of the poor is unleashed. The market is not a zero-sum game, but one that grows with increased economic activity.

\section{c. Nourishing a Sense of Community}

The neorealist school of foreign policy argues that people are concerned with filling their needs, including their psychological needs of security and identity. ${ }^{255}$ The post-Cold War era has made this point painfully on numerous occasions. According to one study, more than $90 \%$ of post Cold War conflicts have occurred within the borders of an existing nation-state and the battles have been on the basis of ethnic, cultural, and religious identity. ${ }^{256}$ Religious historian Scott Appleby has analyzed fundamentalist religious movements in all faiths and argues that it is when a group feels threatened, i.e. their security in their identity is at risk, extremism can take hold. ${ }^{257}$ Extremism is not necessarily violent, but it can be.

In a rare cross-cultural study of attributes of peaceful societies, anthropologist David Fabbro notes that those societies that are relatively small, have a great deal of

${ }^{253}$ See generally, Hernando DeSoto, The Mystery of CAPITAL: Why CAPITAlism WORKS IN THE WEST AND FAILS EVERYWHERE ELSE (2000).

${ }^{254} \mathrm{Id}$.

${ }^{255}$ See See Connie Peck, Sustainable Peace: The Role of the UN and Regional Organizations in Preventing CONFLICT (1998).

${ }^{256} \mathrm{Id}$. 
face-to-face interaction, allow for most, if not all, community members to participate in decisions, are relatively egalitarian (including gender equity), practice nonviolent resolution of conflicts, and are geographically separated from others tend to be more peaceful. ${ }^{258}$ There is not much a company can do to influence geographical separation, but there are things companies can do to mirror the attributes of peaceful societies.

First, businesses can become genuine communities. More specifically, companies can become mediating institutions. As Timothy Fort has argued, there are both moral and neurobiological reasons for why human beings develop their values in relative small groups - mediating institutions - such as family, neighborhood, religious groups, and voluntary associations. ${ }^{259}$ Large bureaucratic companies do not necessarily lend themselves to being communities, but creating a sense of connectedness among members of an organization can provide a sense of security and identity to the people who work there.

As part of this process, the second thing companies can do is to encourage the use of "voice" by those in the company. Having a voice in the promulgation of rules is a critical, identifying characteristic of a democracy. Although subtle, we suggest that when a company committed to quality processes, such as Motorola, insists that its employees speak up when they recognize a product defect, these employees have learned something about participatory governance, and this knowledge may spillover

${ }^{257}$ R. Scott Appleby, The Ambivalence of the SACRed: Religion, Violence, AND RECONCILIATION 17 (2000).

${ }^{258}$ David Fabbro, Peaceful Societies: An Introduction, 15 J. PEACE STUdIES 67 (1978).

${ }^{259}$ Timothy L. FORT, ETHICS AND GOVERNANCE: BUSINESS AS MEDIATING INSTITUTION (2000). 
into the country itself. This could be significant because, as noted above, ${ }^{260}$ democratic countries rarely, if ever, go to war with each other.

Finally, a corporation can contribute to the psychological security and identity of a country by investing in the people of that country. Earlier, the Motorola example of having its Malay plant run by Malay managers was noted. To the extent companies can develop and empower leaders in the countries where their plants are located, the less likely, it would seem, that those plants would be seen as threatening of local culture. This is an area which merits considerably more research.

\section{d. Mediating Between Potentially Conflicting Parties}

Nation states clearly compete for power. We suggest that corporations can play a role in mediating some of the contests for power between people for whom either power or security is at stake through what has become known as "track two" diplomacy. This can happen in three ways.

In general, governmental leaders are typically limited in the people they can talk with in other countries. By diplomatic protocol, they can only talk to other governmental officials. Not only does this limit the number of available conversation partners, it limits the flexibility of negotiations between leaders of countries in the midst of a dispute. Utilizing track two diplomacy, an outside party can relay unofficial messages. For instance, New York Times columnist Thomas Friedman notes that the 2002 nuclear showdown between India and Pakistan was mitigated, at least in part, by the actions of General Electric executives impressing on the Indian government the

\footnotetext{
${ }^{260}$ See George Eckes, The Six Sigma Revolution: How General EleCtric ANd OTHERS TURNED PROCESS INTO PROFITS 1-11 (2000) (particularly with emphasis on quality processes involving management at every level of the organization).
} 
need to come to a peaceful resolution of the conflict. ${ }^{261}$ Businesses, in short, can play a role. Governments interested in expanding power may still bluster at each other, but businesspeople have a perspective of the security and stability that is in play for a variety of participants that needs to be factored into political equations. This is not to suggest that businesspeople become spies for their own governments. Instead, it is for them to provide ways for power-interested politicians to settle disputes with a minimum of social disruption.

A second kind of track two diplomacy is that of corporate citizenship. Businesses can be ambassadors for their countries. In doing so, a more positive vision of the country may emerge. There is a huge literature on the actions corporations can take in order to be constructive citizens in their communities. These actions range from environmental responsibility to respect for human rights to promoting educational opportunities for employees and others beside. We simply suggest that within this vast corporate citizenship literature lies a large number of potential sources of examples for constructive corporate involvement. ${ }^{262}$

A third kind of track two diplomacy might occur in the workplace. A corporation provides the opportunity for different people, perhaps even ethnically conflicting, to work together for a common goal. Sometimes this is explicit; other times it is not. For instance, Futureways, a company in Ireland, purposely hires both Protestants and Catholics, in an approximate 50-50 ratio, for its workforce. ${ }^{263}$ Not only do these often-

261 Thomas L. Friedman, India, Pakistan, and G.E., N.Y. Times (Aug. 11, 2002).

${ }^{262}$ See, e.g. JANE NELSON, THE Business of PEACE 20 (2000) (demonstrating a variety of corporate citizenship examples that are believe to have an impact on reduction of violence).

${ }^{263}$ Id. at 118-19. 
warring populations work together for the goal of a profitable company, they also talk about their experiences with each other. A nonbusiness example of the same philosophy - Seeds of Peace - brings together Israeli and Palestinian youths to a summer camp in New England each year in order to demonstrate that "the enemy has a face."264 People typically walk away from the experience with the "outgroup member" as being a person rather than an enemy. ${ }^{265}$ A less explicit example of this would be a company that simply brings together people from different groups to work together without necessarily promoting explicit discussion of their differences. ${ }^{266}$

Our argument is not that business should take on some kind of messianic purpose. Businesses have a primary role in terms of providing economic growth and opportunity. But businesses can choose to pursue that growth in different ways. This research suggests that business can pursue its work in ways that might contribute to more stability, more security, and more peace in societies.

\section{Conclusion}

Issues of globalization have been present for many years. Corporate power has been increasing for decades if not centuries. Communication technologies allow for relative ease in crossing the borders of sovereign nation states thereby reducing the power of traditional forms of government. Environmental degradation defies neat compartmentalization within geographic boundaries. Nation states are still critically

264 John Wallace, The Enemy Has a Face: The Seeds of Peace ExPerience (2000). ${ }^{265} \mathrm{Id}$.

${ }^{266}$ See, Ronald TAKAKA, A DifFERENT Mirror: A History OF Multicultural AMERICA (1993) (arguing that it is at work where Americans of different ethnic origins meet and learn to work together). 
important organizations, but markets and technologies mark the new millennium as presenting a different set of challenges than what has previously existed.

In a changing environment, those who survive are those who adapt. This is a time where adaptation is necessary. More specifically, those organizations that have the capability to cross borders, move markets, connect individuals and cultures, and bring people to work together have the potential to create either great harm and anguish or great gains. Among these organizations are transnational governmental bodies, such as the United Nations, the World Trade Organization, and many others as well as nongovernmental organizations such as the Red Cross or Transparency International. Yet at the center of the changes impacting the world is the multinational corporation.

In this paper, we have not argued that corporations necessarily have a duty to adapt their policies in order to integrate a quest for sustainable peace among their other financial objectives. Instead, we have suggested that given the changing world and the potential negative impact corporations may have on democracy, it is worth pausing to consider what corporations might be able to do. By incorporating sustainable peace as a business objective, multinational corporations may be able to blend extant corporate governance principles with a goal that can significantly contribute to the reduction of violence in the world.

The arguments are, at best, nascent in form. There is considerable amount of research that needs to be conducted and refinement of the ideas we have articulated. In particular, there is a need for academic scholars as well as members of nongovernmental organizations to more fully explore the extent to which corporate actions have an impact on violence and stability. The reason for this need is not to 
attempt to find blame, but rather to sketch out the relationship is between corporate action and sustainable peace. We would expect that such research will demonstrate an indirect connection. That is, that certain kinds of societies are more prone to violence (and stability) and that corporations contribute to the development of such societies in certain ways.

If this connection can be made, businesses may have a model of how they can act. And, in fact, there are models of good corporate citizenship that are already being linked to sustainable peace. These examples are likely to become important touchstones for other businesses to emulate and to provide the freedom for businesses to think more largely about they might be able to do.

Finally, if there are connections between types of economic productivity and sustainable peace, there may be pressure on governments to create incentives for corporations to contribute to stability by modifying existing governance laws. In the meantime, enough evidence exists to sketch some things companies can do to contribute to peace. That is, they can foster economic development, remain open to external evaluation of corporate actions, act as good corporate citizens in the community and to be a corporate community in its own right, and take advantage of opportunities for track two diplomacy. 


\section{DAVIDSON INSTITUTE WORKING PAPER SERIES - Most Recent Papers}

The entire Working Paper Series may be downloaded free of charge at: www.wdi.bus.umich.edu

CURRENT AS OF $1 / 16 / 03$

\begin{tabular}{|c|c|c|}
\hline Publication & Authors & Date \\
\hline $\begin{array}{l}\text { No. 532: Forthcoming in Vanderbilt Journal of Transnational Law, } \\
\text { "Adapting Corporate Governance for Sustainable Peace" }\end{array}$ & $\begin{array}{l}\text { Timothy L. Fort and Cindy A. } \\
\text { Schipani }\end{array}$ & Jan. 2003 \\
\hline $\begin{array}{l}\text { No. 531: Forthcoming in Vanderbilt Journal of Transnational Law, } \\
\text { "Groundings of Voice in Employee Rights" }\end{array}$ & Dana Muir & Jan. 2003 \\
\hline $\begin{array}{l}\text { No. 530: Forthcoming in Vanderbilt Journal of Transnational Law, } \\
\text { Gender Voice and Correlations with Peace }\end{array}$ & $\begin{array}{l}\text { Morehead Dworkin and Cindy A. } \\
\text { Schipani }\end{array}$ & Jan. 2003 \\
\hline $\begin{array}{l}\text { No. 529: Forthcoming in Vanderbilt Journal of Transnational Law, } \\
\text { "The Organizational Model for Workplace Security" }\end{array}$ & Dr. Thomas K. Capozzoli & Jan. 2003 \\
\hline $\begin{array}{l}\text { No. 528: Forthcoming in Vanderbilt Journal of Transnational Law, } \\
\text { "Nationbuilding 101: Reductionism in Property, Liberty, and Corporate } \\
\text { Governance" }\end{array}$ & O. Lee Reed & Jan. 2003 \\
\hline $\begin{array}{l}\text { No. 527: Forthcoming in Vanderbilt Journal of Transnational Law, "On } \\
\text { Virtue and Peace: Creating a Workplace Where People Can Flourish" }\end{array}$ & $\begin{array}{l}\text { Caryn L. Beck-Dudley and } \\
\text { Steven H. Hanks }\end{array}$ & Jan. 2003 \\
\hline $\begin{array}{l}\text { No. 526: Forthcoming in Vanderbilt Journal of Transnational Law, } \\
\text { "Novartis and the United Nations Global Compact Initiative" }\end{array}$ & Lee A. Tavis & Dec. 2002 \\
\hline $\begin{array}{l}\text { No. 525: Why Transition Paths Differ: Russian and Chinese Enterprise } \\
\text { Performance Compared }\end{array}$ & Sumon Bhaumik and Saul Estrin & Jan. 2003 \\
\hline $\begin{array}{l}\text { No. 524: Official Regulations and the Shadow Economy: A Labour } \\
\text { Market Approach }\end{array}$ & Maxim Bouev & Dec. 2002 \\
\hline No. 523: Children at Risk: Infant and Child Health in Central Asia & Cynthia Buckley & Jan. 2003 \\
\hline No. 522: Wages and International Rent Sharing in Multinational Firms & $\begin{array}{l}\text { John W. Budd, Jozef Konings and } \\
\text { Matthew J. Slaughter }\end{array}$ & July 2002 \\
\hline $\begin{array}{l}\text { No. 521: Gross Job Flows in Ukraine: Size, Ownership and Trade } \\
\text { Effects }\end{array}$ & $\begin{array}{l}\text { Jozef Konings, Olga Kupets and } \\
\text { Hartmut Lehmann }\end{array}$ & Dec. 2002 \\
\hline $\begin{array}{l}\text { No. 520: Entrepreneurial Networking in China and Russia: Comparative } \\
\text { Analysis and Implications for Western Executives }\end{array}$ & Bat Batjargal & Dec. 2002 \\
\hline $\begin{array}{l}\text { No. 519: Agriculture and Income Distribution in Rural Vietnam under } \\
\text { Economic Reforms: A Tale of Two Regions }\end{array}$ & $\begin{array}{l}\text { Dwayne Benjamin and Loren } \\
\text { Brandt }\end{array}$ & Mar. 2002 \\
\hline $\begin{array}{l}\text { No. 518: Property Rights, Labour Markets, and Efficiency in a } \\
\text { Transition Economy: The Case of Rural China }\end{array}$ & $\begin{array}{l}\text { Dwayne Benjamin and Loren } \\
\text { Brandt }\end{array}$ & Mar. 2002 \\
\hline $\begin{array}{l}\text { No. 517: Bank Discrimination in Transition Economies: Ideology, } \\
\text { Information or Incentives? }\end{array}$ & Loren Brandt and Hongbin Li & Oct. 2002 \\
\hline $\begin{array}{l}\text { No. 516: Ex-ante Evaluation of Conditional Cash Transfer Programs: } \\
\text { The Case of Bolsa Escola }\end{array}$ & $\begin{array}{l}\text { François Bourguignon, Francisco } \\
\text { H. G. Ferreira and Phillippe G. } \\
\text { Leite }\end{array}$ & Sep. 2002 \\
\hline No. 515: Missed Expectations: The Argentine Convertibility & $\begin{array}{l}\text { Sebastian Galiani, Daniel } \\
\text { Heymann and Mariano Tommasi }\end{array}$ & Nov. 2002 \\
\hline $\begin{array}{l}\text { No. 514: Job Reallocation and Productivity Growth under Alternative } \\
\text { Economic Systems and Policies: Evidence from the Soviet Transition }\end{array}$ & J. David Brown and John S. Earle & Nov. 2002 \\
\hline $\begin{array}{l}\text { No. 513: Cross-Border Trading as a Mechanism for Capital Flight: } \\
\text { ADRs and the Argentine Crisis }\end{array}$ & $\begin{array}{l}\text { Sebastian Auguste, Kathryn M.E. } \\
\text { Dominguez, Herman Kamil and } \\
\text { Linda L. Tesar }\end{array}$ & Nov. 2002 \\
\hline $\begin{array}{l}\text { No. 512: Embracing the Market: Entry into Self-Employment in } \\
\text { Transitional China, } 1978-1996\end{array}$ & Xiaogang $\mathrm{Wu}$ & Sep. 2002 \\
\hline $\begin{array}{l}\text { No. 511: Opening the Capital Account of Transition Economies: How } \\
\text { Much and How Fast }\end{array}$ & $\begin{array}{l}\text { Daniel Daianu and Radu } \\
\text { Vranceanu }\end{array}$ & Sep. 2002 \\
\hline $\begin{array}{l}\text { No. 510: Bridging "the Great Divide": Countering Financial Repression } \\
\text { in Transition }\end{array}$ & Patrick Conway & May 2002 \\
\hline $\begin{array}{l}\text { No. 509: Change the Regime - Change the Money: Bulgarian } \\
\text { Banknotes, 1885-2001 }\end{array}$ & Adrian E. Tschoegl & May 2002 \\
\hline $\begin{array}{l}\text { No. 508: Differential Rewards to, and Contributions of, Education in } \\
\text { Urban China's Segmented Labor Markets }\end{array}$ & $\begin{array}{l}\text { Margaret Maurer-Fazio and Ngan } \\
\text { Dinh }\end{array}$ & June 2002 \\
\hline $\begin{array}{l}\text { No. 507: Balassa-Samuelson Effect in Transition Economies: The Case } \\
\text { of Slovenia }\end{array}$ & Boštjan Jazbec & Oct. 2002 \\
\hline
\end{tabular}

